Jurnal

Kardiologi Indonesia

J Kardiol Indones. 2014;35:102-33

ISSN $0126 / 3773$

Clinical Guidelines

\title{
2014 Indonesian Heart Association Guidelines of Management of Atrial Fibrillation
}

\author{
Yoga Yuniadi, Dicky A Hanafy, Sunu B Raharjo, , Alexander E Tondas, \\ Erika Maharani, Dony Y Hermanto, Muhammad Munawar
}

Task Force of Arrhythmias of Indonesian Heart Association and Indonesian Heart Rhythm Society
Atrial fibrillation is the most frequent arrhythmia in clinical practice and causing huge health problem. Therefore, a national guidelines in management of $\mathrm{AF}$ that comprise of pathomechanism, clasifications, anticoagulants management for stroke prevention, rate and rhythm control is developed to ensure patients get best therapeutic option. The guidelines is developed in line with variable health care level in Indonesia from primary up to tertiary care.

(J Kardiol Indones. 20 I4;34:102-33)

Keywords: guidelines, atrial fibrillation, Indonesian 


\title{
Pedoman Tata Laksana Fibrilasi Atrium Perhimpunan Dokter Spesialis Kardiovaskular Indonesia 2014
}

\author{
Yoga Yuniadi, Dicky A Hanafy, Sunu B Rahario, , Alexander E Tondas, \\ Erika Maharani, Dony Y Hermanto, Muhammad Munawar
}

\begin{abstract}
Fibrilasi atrium (FA) merupakan aritmia yang paling sering ditemui di klinik dan memiliki dampak kesehatan yang besar. Oleh karena itu dibuat pedoman tatalaksana FA yang komprehensif meliputi patomekanisme, klasifikasi, tatalaksana antikoagulan untuk pencegahan stroke, kendali laju dan kendali irama agar menjamin manfaat terbaik bagi pasien. Pedoman ini disajikan dengan memperhitungkan berbagai tingkat layanan kesehatan mulai dari primer hingga tersier.
\end{abstract}

(J Kardiol Indones. 2014;35:102-33)

Kata kunci: panduan, fibrilasi atrial, Indonesia

\section{PENDAHULUAN}

\section{I. Latar belakang dan epidemiologi}

Fibrilasi atrium (FA) merupakan aritmia yang paling sering ditemui dalam praktik sehari-hari. Prevalensi FA mencapai $1-2 \%$ dan akan terus meningkat dalam $5 \mathrm{O}$ tahun mendatang. ${ }^{1,2}$ Framingham Heart Study yang merupakan suatu studi kohor pada tahun 1948 dengan melibatkan 5209 subjek penelitian sehat (tidak menderita penyakit kardiovaskular) menunjukkan bahwa dalam periode 20 tahun, angka kejadian FA

\footnotetext{
Alamat Korespondensi

Dr. dr. Yoga Yuniadi, SpJP. Divisi Aritmia, Departemen Kardiologi dan Kedokteran Vaskular, FKUI dan Pusat Jantung Nasional Harapan Kita, Jakarta. E-mail: yogayI36@gmail.com
}

adalah $2,1 \%$ pada laki-laki dan $1,7 \%$ pada perempuan. ${ }^{3}$ Sementara itu data dari studi observasional (MONICA multinational MONItoring of trend and determinant in CArdiovascular disease) pada populasi urban di Jakarta menemukan angka kejadian FA sebesar 0,2\% dengan rasio laki-laki dan perempuan 3:2. ${ }^{4}$ Selain itu, karena terjadi peningkatan signifikan persentase populasi usia lanjut di Indonesia yaitu 7,74\% (pada tahun 2000-2005) menjadi 28,68\% (estimasi WHO tahun 2045-2050), ${ }^{5}$ maka angka kejadian FA juga akan meningkat secara signifikan. Dalam skala yang lebih kecil, hal ini juga tercermin pada data di Rumah Sakit Jantung dan Pembuluh Darah Harapan Kita yang menunjukkan bahwa persentase kejadian FA pada pasien rawat selalu meningkat setiap tahunnya, yaitu $7,1 \%$ pada tahun 2010 , meningkat menjadi $9,0 \%$ (2011), 9,3\% (2012) dan 9,8\% (2013). 
Fibrilasi atrium menyebabkan peningkatan mortalitas dan morbiditas, termasuk stroke, gagal jantung serta penurunan kualitas hidup. Pasien dengan FA memiliki risiko stroke 5 kali lebih tinggi dan risiko gagal jantung 3 kali lebih tinggi dibanding pasien tanpa FA. ${ }^{6}$ Stroke merupakan salah satu komplikasi FA yang paling dikhawatirkan, karena stroke yang diakibatkan oleh FA mempunyai risiko kekambuhan yang lebih tinggi. Selain itu, stroke akibat FA ini mengakibatkan kematian dua kali lipat dan biaya perawatan 1,5 kali lipat. $^{7}$

Fibrilasi atrium juga berkaitan erat dengan penyakit kardiovaskular lain seperti hipertensi, gagaI jantung, penyakit jantung koroner, hipertiroid, diabetes melitus, obesitas, penyakit jantung bawaan seperti defek septum atrium, kardiomiopati, penyakit ginjal kronis maupun penyakit paru obstruktif kronik (PPOK). GagaI jantung simtomatik dengan kelas fungsional New York Heart Association (NYHA) II sampai IV dapat terjadi pada $30 \%$ pasien FA, namun sebaliknya FA dapat terjadi pada $30-40 \%$ pasien dengan gagal jantung tergantung dari penyebab dari gagal jantung itu sendiri. Fibrilasi atrium dapat menyebabkan gagaI jantung melalui mekanisme peningkatan tekanan atrium, peningkatan beban volume jantung, disfungsi katup dan stimulasi neurohormonal yang kronis. Distensi pada atrium kiri dapat menyebabkan FA seperti yang terjadi pada pasien penyakit katup jantung dengan prevalensi sebesar $30 \%$ dan $10-15 \%$ pada defek septal atrium. Sekitar $20 \%$ populasi pasien FA mengalami penyakit jantung koroner meskipun keterkaitan antara FA itu sendiri dengan perfusi koroner masih belum jelas. ${ }^{9}$

\section{I.2. Patofisiologi fibrilasi atrium (FA)}

Sampai saat ini patofisiologi terjadinya FA masih belum sepenuhnya dipahami dan dipercaya bersifat multifaktorial. Dua konsep yang banyak dianut tentang mekanisme FA adalah 1) adanya faktor pemicu (trigger); dan 2) faktor-faktor yang melanggengkan. Pada pasien dengan FA yang sering kambuh tetapi masih dapat konversi secara spontan, mekanisme utama yang mendasari biasanya karena adanya faktor pemicu (trigger) FA, sedangkan pada pasien FA yang tidak dapat konversi secara spontan biasanya didominasi adanya faktor-faktor yang melanggengkan. ${ }^{9}$

\section{I.2.1. Perubahan patofisiologis yang mendahului terjadinya FA}

Berbagai jenis penyakit jantung struktural dapat memicu remodelling yang perlahan tetapi progresif baik di ventrikel maupun atrium. Proses remodelling yang terjadi di atrium ditandai dengan proliferasi dan diferensiasi fibroblas menjadi miofibroblas yang dapat meningkatkan deposisi jaringan ikat dan fibrosis di atrium. Proses remodelling atrium menyebabkan gangguan elektris antara serabut otot dan serabut konduksi di atrium, serta menjadi faktor pemicu sekaligus faktor yang melanggengkan terjadinya FA. Substrat elektroanatomis ini memfasilitasi terjadinya sirkuit reentri yang akan melanggengkan terjadinya aritmia. ${ }^{2}$

Sistem saraf simpatis maupun parasimpatis di dalam jantung juga memiliki peran yang penting dalam patofisiologi FA, yaitu melalui peningkatan $\mathrm{Ca}^{2+}$ intraselular oleh sistem saraf simpatis dan pemendekan periode refrakter efektif atrium oleh sistem saraf parasimpatis (vagal). ${ }^{10}$ Stimulasi pleksus ganglionik akan memudahkan terangsangnya FA melalui vena pulmoner (VP), sehingga pleksus ganglionik dapat dipertimbangkan sebagai salah satu target ablasi. Namun, manfaat ablasi pleksus ganglionik sampai sekarang masih belum jelas. ${ }^{11}$

Setelah munculnya FA, perubahan sifat elektrofisiologis atrium, fungsi mekanis, dan ultra struktur atrium terjadi pada rentang waktu dan dengan konsekuensi patofisiologis yang berbeda. Sebuah studi melaporkan terjadinya pemendekan periode refrakter efektif atrium pada hari-hari pertama terjadinya FA. ${ }^{12}$ Proses remodelling elektrikal memberikan kontribusi terhadap peningkatan stabilitas FA selama hari-hari pertama setelah onset. Mekanisme selular utama yang mendasari pemendekan periode refrakter adalah penurunan (down regulation) arus masuk kalsium (melalui kanal tipe-L) dan peningkatan (upregulation) arus masuk kalium. Beberapa hari setelah kembali ke irama sinus, maka periode refrakter atrium akan kembali normal. ${ }^{2}$

Gangguan fungsi kontraksi atrium juga terjadi pada beberapa hari setelah terjadinya FA. Mekanisme yang mendasari gangguan ini adalah penurunan arus masuk kalsium, hambatan pelepasan kalsium intraselular dan perubahan pada energetika miofibril. ${ }^{13}$

\subsubsection{Mekanisme elektrofisiologis}

Awitan dan keberlangsungan takiaritmia membutuh- 
kan adanya pemicu (trigger) dan substrat. Atas dasar itu, mekanisme elektrofisiologis FA dapat dibedakan menjadi mekanisme fokal karena adanya pemicu dan mekanisme reentri mikro (multiple wavelet hypothesis) karena adanya substrat (gambar 1 ). Meskipun demikian, keberadaan kedua hal ini dapat berdiri sendiri atau muncul bersamaan. ${ }^{9,13}$

\section{Mekanisme fokal}

Mekanisme fokal adalah mekanisme FA dengan pemicu dari daerah-daerah tertentu, yakni $72 \%$ di VP dan sisanya (28\%) bervariasi dari vena kava superior $(37 \%)$,dinding posterior atrium kiri $(38,3 \%)$, krista terminalis $(3,7 \%)$, sinus koronarius (1,4\%), ligamentum Marshall (8,2\%), dan septum interatrium. Mekanisme seluler dari aktivitas fokal mungkin melibatkan mekanisme triggered activity dan reentri. Vena pulmoner memiliki potensi yang kuat untuk memulai dan melanggengkan takiaritmia atrium, karena VP memiliki periode refrakter yang lebih pendek serta adanya perubahan drastis orientasi serat miosit. ${ }^{2}$

Pada pasien dengan FA paroksismal,intervensi ablasi di daerah pemicu yang memiliki frekuensi tinggi dan dominan (umumnya berada pada atau dekat dengan batas antara VP dan atrium kiri) akan menghasilkan pelambatan frekuensi FA secara progresif dan selanjutnya terjadi konversi menjadi irama sinus. Sedangkan pada pasien dengan FA persisten, daerah yang memiliki frekuensi tinggi dan dominan tersebar di seluruh atrium, sehingga lebih sulit untuk melakukan tindakan ablasi atau konversi ke irama sinus. ${ }^{2,9,13}$

\section{Mekanisme reentri mikro (multiple wavelet hypothesis)}

Dalam mekanisme reentri mikro, FA dilanggengkan oleh adanya konduksi beberapa wavelet independen secara kontinyu yang menyebar melalui otot-otot atrium dengan cara yang kacau. Hipotesis ini pertama kali dikemukakan oleh Moe yang menyatakan bahwa FA dilanggengkan oleh banyaknya wavelet yang tersebar secara acak dan saling bertabrakan satu sama lain dan kemudian padam,atau terbagi menjadi banyak wavelet lain yang terus-menerus merangsang atrium. Oleh karenanya, sirkuit reentri ini tidak stabil, beberapa menghilang, sedangkan yang lain tumbuh lagi. Sirkuit-sirkuit ini memiliki panjang siklus yang bervariasi tapi pendek. Diperlukan setidaknya 4-6 wavelet mandiri untuk melanggengkan FA. ${ }^{14}$
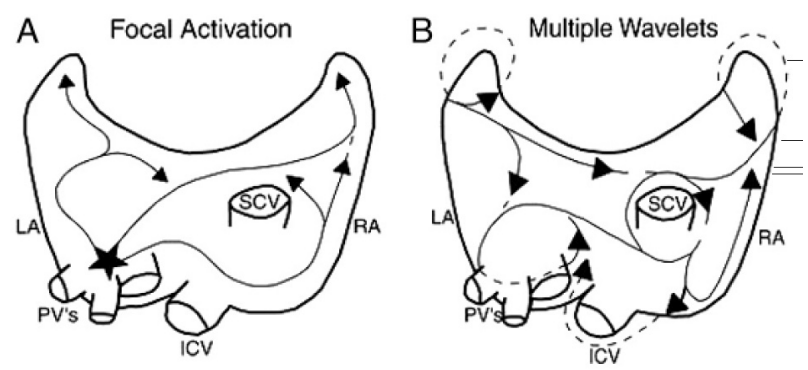

Gambar 1. Mekanisme elektrofisiologis FA. A. Mekanisme fokal: fokus/pemicu (tanda bintang) sering ditemukan di vena pulmoner. B. Mekanisme reentri mikro: banyak wavelet independen yang secara kontinu menyebar melalui otot-otot atrium dengan cara yang kacau. AKi: atrium kiri, AKa: atrium kanan, VP: vena pulmoner, VKI: vena kava inferior, VKS: vena kava superior (dimodifikasi dari referensi 15).

\section{Fibrilasi atrium menyulut FA ( $A F$ begets $A F$ )}

Konsep FA menyulut FA dikemukakan pertama kali oleh Alessie dkk. dalam sebuah eksperimen pada kambing. Observasi mereka menunjukkan bahwa pemacuan atrium dengan teknik pacurentet (burst pacing) akan menyebabkan FA, yang akan kembali ke irama sinus. Kemudian bila dilakukan pacu-rentet lagi akan muncul FA kembali. Apabila proses ini dilakukan terus menerus, maka durasi FA akan bertambah lama sampai lebih dari 24 jam. ${ }^{15}$ Oleh karena itu pada pasien yang mengalami FA paroksismal dapat berkembang menjadi FA persisten atau permanen.

\section{I.2.2. Predisposisi genetik}

Fibrilasi atrium memiliki komponen herediter, terutama FA awitan dini. ${ }^{16}$ Selama beberapa tahun terakhir, banyak sindrom jantung bawaan terkait dengan FA telah diidentifikasi. Sindrom QT pendek dan QT panjang, serta sindrom Brugada berhubungan dengan supraventrikular aritmia, termasuk FA. ${ }^{17}$ Fibrilasi atrium juga sering terjadi pada berbagai kondisi yang diturunkan (inherited), termasuk kardiomiopati hipertrofi, dan hipertrofi ventikel kiri abnormal yang terkait dengan mutasi pada gen PRKAG. Bentuk herediter lain dari FA berhubungan 
dengan mutasi pada gen yang mengode peptida atrial natriuretik, ${ }^{18}$ mutasi loss-of-function pada gen kanaI natrium SCNSA, ${ }^{19}$ atau gain-of-function pada gen kanal kalium. ${ }^{20}$ Selain itu, beberapa lokus genetik yang dekat dengan gen PITX2 dan ZFHX3 berhubungan dengan FA dan stroke kardioembolik. ${ }^{21}$

\subsection{Konsekuensi klinis FA}

\section{Konduksi atrioventrikular}

Pada pasien FA dengan sistem konduksi yang normal (tidak adanya jaras tambahan maupun disfungsi serabut His-Purkinje), nodus atrioventrikular (NAV) berfungsi sebagai filter untuk mencegah laju ventrikel yang berlebihan. Mekanisme utama yang membatasi konduksi atrioventrikular adalah periode refrakter intrinsik dari NAV dan konduksi tersembunyi (concealed). Pada konduksi tersembunyi, impuls listrik yang mencapai NAV mungkin tidak diteruskan ke ventrikel, tetapi dapat mengubah periode refrakter NAV sehingga dapat memperlambat atau menghambat denyut atrium berikutnya. ${ }^{?}$

Fluktuasi tonus simpatis dan parasimpatis menyebabkan perubahan kecepatan konduksi impuls listrik melalui NAV. Hal ini menimbulkan variabilitas laju ventrikel selama siklus diurnal atau saat latihan. Laju ventrikel dengan variabilitas yang tinggi ini secara terapeutik sering menjadi tantangan sendiri. Digitalis, yang berefek memperlambat laju ventrikel dengan meningkatkan tonus parasimpatis,merupakan terapi yang efektif untuk mengendalikan laju jantung saat istirahat, tetapi kurang efektif saat aktifitas. Penghambat reseptor beta dan antagonis kanal kalsium golongan non-dihidropiridin dapat memperlambat laju ventrikel baik saat istirahat maupun saat latihan. ${ }^{2}$

Pada pasien FA dengan sindrom preeksitasi

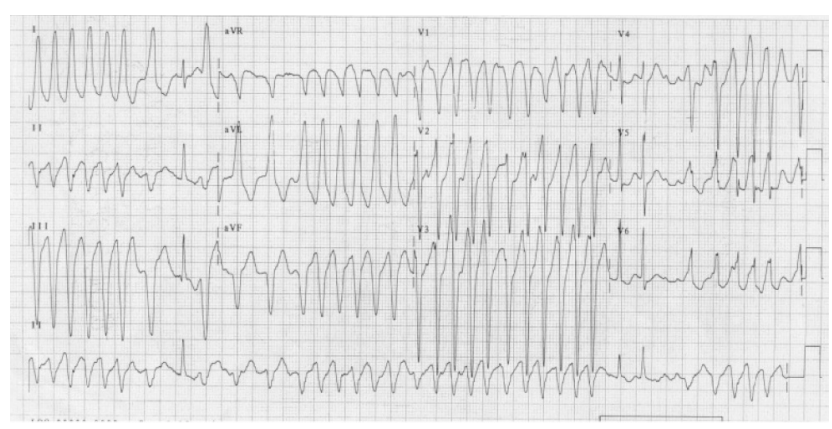

Gambar 2. Elektrokardiogram fibrilasi atrium pada Sindrom Wolff-Parkinson-White (WPW). (sindrom Wolff Parkinson-White/WPW) (gambar 2) dapat terjadi laju ventrikel yang cepat dan berpotensi mengancam jiwa. Hal ini terjadi karena impuls FA yang melalui jaras tambahan tidak mengalami pelambatan/filter sebagaimana jika melalui NAV. Pada keadaan di atas, pemberian obat yang memperlambat konduksi NAV tanpa memperpanjang periode refrakter dari atrium/jaras tambahan (misalnya verapamil, diltiazem, dan digitalis) akan mempercepat konduksi melalui jaras tambahan. ${ }^{2,13}$

\section{Perubahan hemodinamik}

Faktor yang mempengaruhi fungsi hemodinamik pada pasien FA meliputi hilangnya kontraksi atrium yang terkoordinasi, tingginya laju ventrikel, ketidakteraturan respon ventrikel, penurunan aliran darah miokard, serta perubahan jangka panjang seperti kardiomiopati atrium dan ventrikel. Hilangnya fungsi koordinasi mekanikal atrium secara akut pada saat terjadinya FA dapat mengurangi curah jantung sampai dengan $5-30 \% .{ }^{22}$ Efek ini terlihat lebih jelas pada pasien dengan penurunan daya regang (compliance) ventrikel oleh karena pada pasien ini kontraksi atrium memberi kontribusi besar dalam pengisian ventrikel. Laju ventrikel yang cepat mengurangi pengisian ventrikel karena pendeknya interval diastolik. Laju ventrikel yang cepat (>120-130 kali per menit) dapat mengakibatkan terjadinya takikardiomiopati ventrikel bila berlangsung lama. ${ }^{23}$ Pengurangan laju jantung dapat menormalkan kembali fungsi ventrikel dan mencegah dilatasi lebih lanjut.

\section{Tromboemboli}

Resiko stroke dan emboli sistemik pada pasien dengan FA didasari sejumlah mekanisme patofisiologis, yaitu 1) abnormalitas aliran darah, 2) abnormalitas endokard, dan 3) unsur darah. Abnormalitas aliran darah ditandai dengan stasis aliran darah di atrium kiri akan menyebabkan penurunan kecepatan aliran pada aurikel atrium kiri (AAK) yang dapat terlihat sebagai spontaneous echo-contrast pada ekokardiografi. Pada FA non-valvular, AAK merupakan sumber emboli yang utama (>90\%). Abnormalitas endokard terdiri dari dilatasi atrium yang progresif, denudasi endokard, dan infiltrasi fibroelastik dari matriks ekstraseluler. Sedangkan, abnormalitas unsur darah berupa aktivasi hemostatik dan trombosit, peradangan dan kelainan faktor pertumbuhan dapat ditemukan pada FA. ${ }^{24}$ 


\section{DIAGNOSIS}

\section{II.I. Definisi}

Fibrilasi atrium adalah takiaritmia supraventrikular yang khas, dengan aktivasi atrium yang tidak terkoordinasi mengakibatkan perburukan fungsi mekanis atrium. Pada elektrokardiogram (EKG), ciri dari FA adalah tiadanya konsistensi gelombang $\mathrm{P}$, yang digantikan oleh gelombang getar (fibrilasi) yang bervariasi amplitudo, bentuk dan durasinya. Pada fungsi NAV yang normal, FA biasanya disusul oleh respons ventrikel yang juga ireguler,dan seringkali cepat. $^{25}$

Ciri-ciri FA pada gambaran EKG umumnya sebagai berikut: ${ }^{26}$

1. EKG permukaan menunjukkan pola interval $R R$ yang ireguler.

2. Tidak dijumpainya gelombang $P$ yang jelas pada EKG permukaan. Kadang-kadang dapat terlihat aktivitas atrium yang ireguler pada beberapa sadapan EKG,paling sering pada sadapan V1.

3. Interval antara dua gelombang aktivasi atrium tersebut biasanya bervariasi, umumnya kecepatannya melebihi 450x/menit.

\section{II.2. Klasifikasi}

Secara klinis FA dapat dibedakan menjadi lima jenis menurut waktu presentasi dan durasinya,yaitu: ${ }^{26}$

1. FA yang pertama kali terdiagnosis. Jenis ini berlaku untuk pasien yang pertama kali datang dengan manifestasi klinis FA, tanpa memandang durasi atau berat ringannya gejala yang muncul.

2. FA paroksismal adalah FA yang mengalami terminasi spontan dalam 48 jam, namun dapat berlanjut hingga 7 hari.

3. FA persisten adalah FA dengan episode menetap hingga lebih dari 7 hari atau FA yang memerlukan kardioversi dengan obat atau listrik.

4. FA persisten lama (long standing persistent) adalah FA yang bertahan hingga 1 tahun, dan strategi kendali irama masih akan diterapkan.

5. FA permanen merupakan FA yang ditetapkan sebagai permanen oleh dokter (dan pasien) sehingga strategi kendali irama sudah tidak digunakan lagi. Apabila strategi kendali irama masih digunakan maka FA masuk ke kategori FA persisten lama.
Klasifikasi FA seperti di atas tidaklah selalu eksklusif satu sama lain (gambar 3). Artinya, seorang pasien mungkin dapat mengalami beberapa episode FA paroksismal, dan pada waktu lain kadang-kadang FA persisten, atau sebaliknya. Untuk itu, secara praktis, pasien dapat dimasukkan ke salah satu kategori di atas berdasarkan manifestasi klinis yang paling dominan.

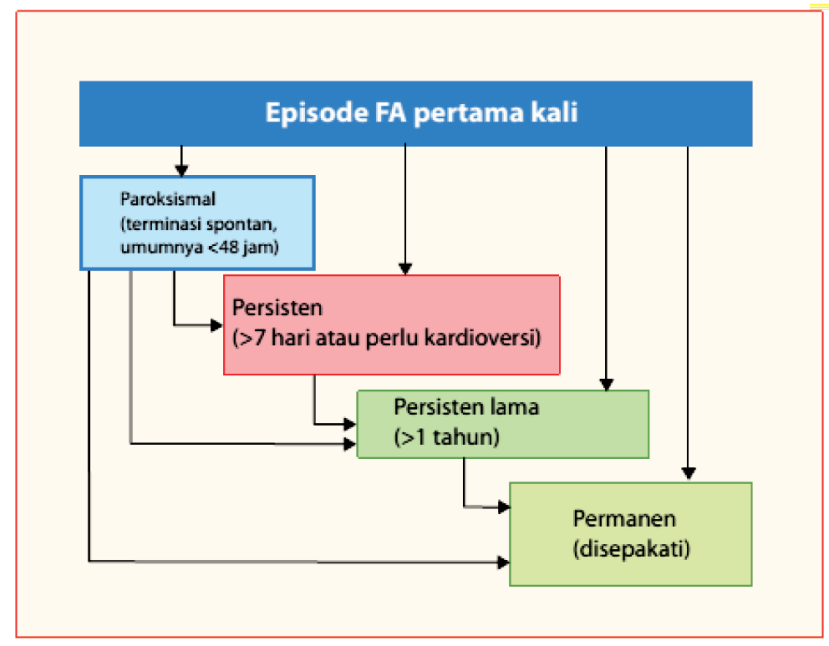

Gambar 3. Klasifikasi FA menurut waktu presentasinya. Fibrilasi atrium dapat mengalami progresivitas dari paroksismal menjadi persisten, persisten lama atau permanen. Seluruh tipe FA tersebut dapat merupakan presentasi awal atas dasar riwayat sebelumnya (disadur dari referensi 2).

Selain dari 5 kategori yang disebutkan diatas, yang terutama ditentukan oleh awitan dan durasi episodenya, terdapat beberapa kategori FA tambahan menurut ciri-ciri dari pasien: ${ }^{27}$

- FA sorangan (lone): FA tanpa disertai penyakit struktur kardiovaskular lainnya, termasuk hipertensi, penyakit paru terkait atau abnormalitas anatomi jantung seperti pembesaran atrium kiri, dan usia di bawah 60 tahun.

- FA non-valvular: FA yang tidak terkait dengan penyakit rematik mitral, katup jantung protese atau operasi perbaikan katup mitral.

- FA sekunder: FA yang terjadi akibat kondisi primer yang menjadi pemicu FA, seperti infark miokard akut, bedah jantung, miokarditis, hipertiroidisme, emboli paru, pneumonia, atau penyakit paru akut lainnya. Sedangkan FA sekunder yang berkaitan dengan penyakit katup disebut FA valvular. 
Respon ventrikel terhadap FA, sangat tergantung pada sifat elektrofisiologi dari NAV dan jaringan konduksi lainnya, derajat tonus vagal serta simpatis, ada atau tiadanya jaras konduksi tambahan, dan reaksi obat.

Berdasarkan kecepatan laju respon ventrikel (interval RR) maka FA dapat dibedakan menjadi [gambar $4(\mathrm{~A}, \mathrm{~B}, \mathrm{C})]$ :

1. FA dengan respon ventrikel cepat: Laju ventrikel $>100 x /$ menit.

2. FA dengan respon ventrikel normal: Laju ventrikel $60-100 x /$ menit.

3. FA dengan respon ventrikel lambat: Laju ventrikel $<60 \mathrm{x} /$ menit.

Menentukan laju jantung dapat menggunakan RR. Laju jantung yang tidak beraturan seperti pada FA, dapat dihitung dengan mengalikan rerata laju jantung dalam 6 detik (30 kotak besar) dikalikan dengan 10 .

Dengan kecepatan kertas EKG standar $25 \mathrm{~mm} /$ detik,maka:

$\begin{array}{ll}\text { - } \quad 1 \text { kotak kecil } & =0,04 \text { detik } \\ \text { - } \quad 1 \text { kotak besar } & =0,2 \text { detik } \\ \text { - } \quad 5 \text { kotak besar } & =1 \text { detik } \\ \text { - } \quad 30 \text { kotak besar } & =6 \text { detik }\end{array}$

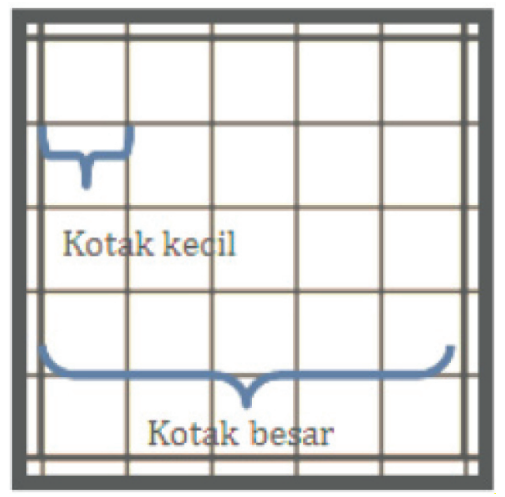

Pada contoh EKG gambar $4 \mathrm{C}$ di atas, dalam 6 detik (30 kotak besar) didapatkan 4 gelombang QRS, sehingga laju jantung adalah $4 \times 10=40 \mathrm{x} /$ menit. Fibrilasi atrium dengan laju jantung $<60 x /$ menit dikategorikan sebagai FA dengan respon ventrikel lambat.

Interval RR yang reguler mungkin terjadi apabila terdapat blok atrioventrikular dengan irama pengganti (escape rhythm) junctional, subjunctional atau ventrikular. Pada pasien dengan pacu jantung permanen, diagnosis FA mungkin memerlukan inhibisi sementara dari pacu jantung agar aktivitas fibrilasi

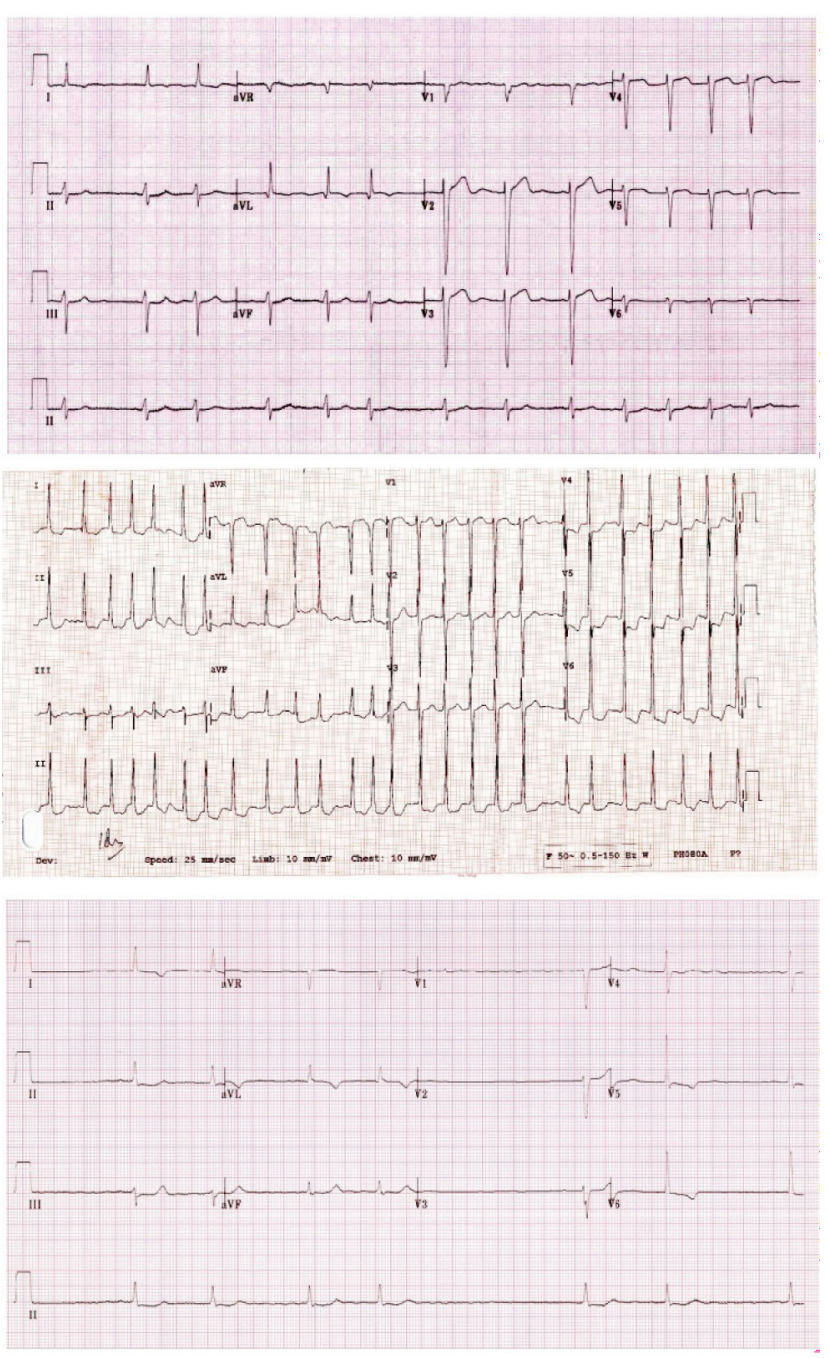

Gambar 4. Rekaman EKG FA. A. FA dengan respon ventrikel normal, B. FA dengan respon ventrikel cepat, C. FA dengan respon ventrikel lambat.

atrium dapat terlihat. Takikardia yang cepat, ireguler, dan menetap dengan kompleks QRS yang lebar mengindikasikan FA dengan konduksi melalui jaras tambahan atau FA dengan blok berkas cabang. ${ }^{28,29}$

\section{II.3. Aritmia lain yang terkait}

Fibrilasi atrium dapat terjadi secara terisolasi atau berhubungan dengan aritmia lainnya, paling sering kepak atrium (atrial flutter) atau takikardia atrium. Kepak atrium (KA) dapat terjadi selama pengobatan dengan agen antiaritmia untuk mencegah rekurensi FA. Perbedaannya adalah pada KA yang tipikal, terdapat pola aktivasi atrium yang reguler berupa gigi gergaji 
pada rekaman EKG atau disebut gelombang kepak (f), terutama nampak jelas pada sadapan II, III, aVF dan V1. Secara alami, laju atrium pada KA tipikal sedikit lebih lambat dari FA, umumnya berkisar antara 240$320 \mathrm{x} /$ menit, dengan aksis gelombang $\mathrm{f}$ negatif pada sadapan II, III, aVF serta positif di V1. Arah aktivasi pada atrium kanan dapat terbalik, sehingga gelombang $f$ positif di sadapan II, III, aVF dan negatif di V1 (disebut tipikal terbalik). Kepak atrium seringkali juga terjadi dengan blok AV 2:1 sehingga bermanifestasi sebagai laju ventrikel reguler atau ireguler berkisar 120-160x/ menit (rata-rata 150x/menit).

Kepak atrium dapat berdegenerasi menjadi FA dan FA dapat mengalami konversi menjadi KA. Pola EKG mungkin berfluktuasi antara KA dan FA, sebagai cerminan peralihan aktivasi dalam atrium. Takikardia atrium fokal, takikardia reentri atrioventrikular dan takikardia reentri NAV mungkinjuga dapat memicu FA. Pada takikardia supraventrikular lainnya seperti disebut di atas, gelombang $\mathrm{P}$ umumnya dapat diidentifikasi dengan jelas dan memiliki garis isoelektrik pada 1 atau lebih sadapan EKG. Morfologi dari gelombang P dapat membantu melokalisasi asal dari takikardia. ${ }^{30}$

\section{II.4. Penegakan diagnosis}

Dalam penegakan diagnosis FA, terdapat beberapa pemeriksaan minimal yang harus dilakukan dan pemeriksaan tambahan sebagai pelengkap. Pada panduan ini, rekomendasi yang diberikan dapat disesuaikan dengan tingkat kelengkapan pusat kesehatan terkait. (lihat Gambar 5 dan 6).

\section{II.4.1. Anamnesis}

Spektrum presentasi klinis FA sangat bervariasi, mulai dari asimtomatik hingga syok kardiogenik atau kejadian serebrovaskular berat. Hampir > 50\% episode FA tidak menyebabkan gejala (silent atrial fibrillation). ${ }^{31}$ Beberapa gejala ringan yang mung kin dikeluhkan pasien antara lain:

- Palpitasi. Umumnya diekspresikan oleh pasien sebagai: pukulan genderang, gemuruh guntur, atau kecipak ikan di dalam dada. ${ }^{32}$

- Mudah lelah atau toleransi rendah terhadap aktivitas fisik

- Presinkop atau sinkop

- Kelemahan umum,pusing

Selain itu, FA juga dapat menyebabkan gangguan

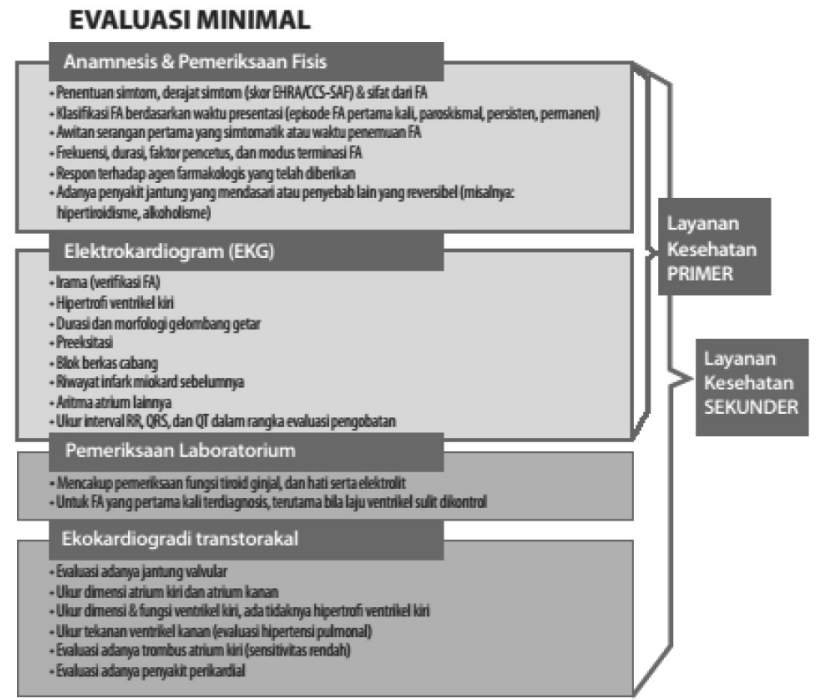

Gambar 5. Evaluasi minimal yang dapat dilakukan di layanan kesehatan primer dan sekunder.

\section{EVALUASI TAMBAHAN}

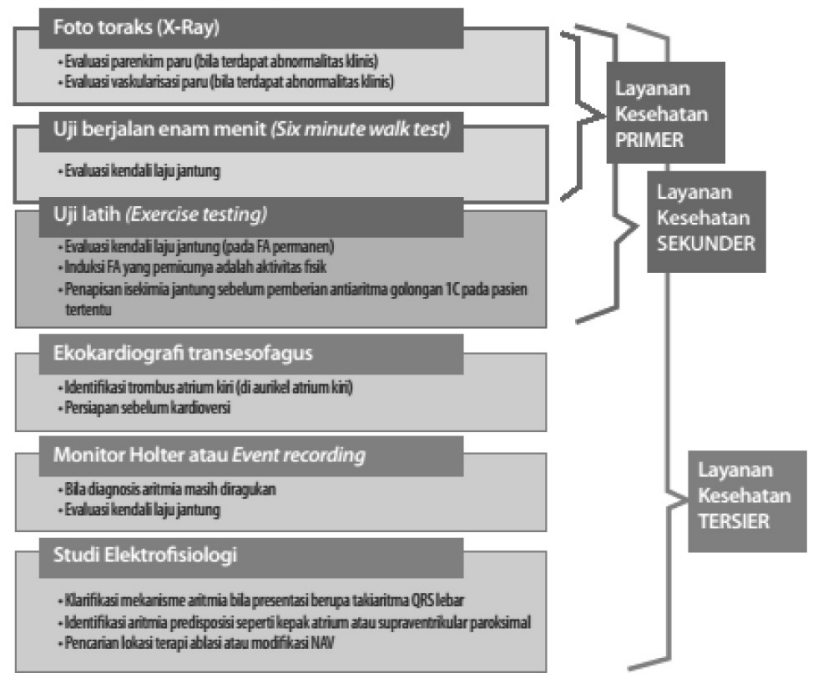

Gambar 6. Evaluasi tambahan yang dapat dilakukan di layanan kesehatan primer, sekunder, dan tersier.

hemodinamik, kardiomiopati yang diinduksi oleh takikardia, dan trombo embolisme sistemik. Penilaian awal dari pasien dengan FA yang baru pertama kali terdiagnosis harus berfokus pada stabilitas hemodinamik dari pasien. ${ }^{33}$

Selain mencari gejala-gejala tersebut diatas, anamnesis dari setiap pasien yang dicurigai mengalami FA harus meliputi pertanyaan pertanyaan yang relevan, seperti: ${ }^{34}$

- Penilaian klasifikasi FA berdasarkan waktu 
presentasi, durasi, dan frekuensi gejala.

- Penilaian faktor-faktor presipitasi (misalnya aktivitas, tidur, alkohol).Peran kafein sebagai faktor pemicu masih kontradiktif. ${ }^{35}$

- Penilaian cara terminasi (misalnya manuver vagal).

- Riwayat penggunaan obat antiaritmia dan kendali laju sebelumnya.

- Penilaian adakah penyakit jantung structural yang mendasarinya.

Tabel 1. Pertanyaan yang relevan untuk ditanyakan pada pasien yang dicurigai atau diketahui FA. ${ }^{26}$

Daftar pertanyaan
Apakah irama jantung saat episode serangan terasa teratur atau tidak
teratur?
Apakah terdapat faktor pencetus seperti aktivitas fisik, emosi atau
asupan alkohol?
Apakah gejala selama episode terasa sedang atau berat - derajat
keparahan dapat diekspresikan dengan menggunakan skor EHRA
Apakah episode yang dirasakan sering atau jarang, dan apakah singkat
atau cukup lama?
Apakah terdapat riwayat penyakit penyerta seperti: hipertensi, penyakit
jantung koroner, gagal jantung, penyakit vaskular perifer, penyakit
serebrovaskular, stroke, diabetes atau penyakit paru kronik?
Apakah ada riwayat penyalahgunaan alkohol ?
Apakah ada riwayat keluarga dengan FA?

- Riwayat prosedur ablasi FA secara pembedahan (operasi Maze) atau perkutan (dengan kateter).

- Evaluasi penyakit-penyakit komorbiditas yang memiliki potensi untuk berkontribusi terhadap inisiasi FA (misalnya hipertensi, penyakitjantung koroner,diabetes melitus, hipertiroid,penyakit jantung valvular,dan PPOK).

\section{II.4.2. Pemeriksaan fisis}

Pemeriksaan fisis selalu dimulai dengan pemeriksaan jalan nafas (Airway), pernafasan (Breathing) dan sirkulasi (Circulation) dan tanda-tanda vital, untuk mengarahkan tindak lanjut terhadap FA. Pemeriksaan fisis juga dapat memberikan informasi tentang dasar penyebab dan gejala sisa dari FA. ${ }^{34}$

\section{Tanda Vital}

Pengukuran laju nadi, tekanan darah, kecepatan nafas dan saturasi oksigen sangat penting dalam evaluasi stabilitas hemodinamik dan kendali laju yang adekuat pada FA. Pada pemeriksaan fisis, denyut nadi umumnya ireguler dan cepat, sekitar 110-140x/ menit, tetapi jarang melebihi 160-170x/menit. Pasien dengan hipotermia atau dengan toksisitas obat jantung (digitalis) dapat mengalami bradikadia.

\section{Kepala dan Leher}

Pemeriksaan kepala dan leher dapat menunjukkan eksoftalmus, pembesaran tiroid, peningkatan tekanan vena jugular atau sianosis. Bruit pada arteri karotis mengindikasikan penyakit arteri perifer dan kemungkinan adanya komorbiditas penyakit jantung koroner.

\section{Paru}

Pemeriksaan paru dapat mengungkap tanda-tanda gagal jantung (misalnya ronki, efusi pleura). Mengi atau pemanjangan ekspirasi mengindikasikan adanya penyakit paru kronik yang mungkin mendasari terjadinya FA (misalnya PPOK,asma)

\section{Jantung}

Pemeriksaan jantung sangat penting dalam pemeriksaan fisis pada pasien FA. Palpasi dan auskultasi yang menyeluruh sangat penting untuk mengevaluasi penyakit jantung katup atau kardiomiopati. Pergeseran dari punctum maximum atau adanya bunyi jantung tambahan (S3) mengindikasikan pembesaran ventrikel dan peningkatan tekanan ventrikel kiri. Bunyi II (P2) yang mengeras dapat menandakan adanya hipertensi pulmonal.

Pulsus defisit, dimana terdapat selisih jumlah nadi yang teraba dengan auskultasi laju jantung dapat ditemukan pada pasien FA.

\section{Abdomen}

Adanya asites, hepatomegali atau kapsul hepar yang teraba mengencang dapat mengindikasikan gagal jantung kanan atau penyakit hati intrinsik. Nyeri kuadran kiri atas, mungkin disebabkan infark limpa akibat embolisasi perifer.

\section{Ekstremitas bawah}

Pada pemeriksaan ekstremitas bawah dapat ditemukan sianosis, jari tabuh atau edema. Ekstremitas 
yang dingin dan tanpa nadi mungkin mengindikasikan embolisasi perifer. Melemahnya nadi perifer dapat mengindikasikan penyakit arterial perifer atau curah jantung yang menurun.

\section{Neurologis}

Tanda-tanda Transient Ischemic Attack (TIA) atau kejadian serebrovaskular terkadang dapat ditemukan pada pasien FA. Peningkatan refleks dapat ditemukan pada hipertiroidisme.

\section{II.4.3. Pemeriksaan laboratorium}

Pemeriksaan laboratorium ditujukan untuk mencari gangguan/penyakit yang tersembunyi, terutama apabila laju ventrikel sulit dikontrol. Satu studi menunjukkan bahwa elevasi ringan troponin I saat masuk rumah sakit terkait dengan mortalitas dan kejadian kardiak yang lebih tinggi, dan mungkin berguna untuk stratifikasi risiko. ${ }^{36}$

Pemeriksaan laboratorium yang dapat diperiksa antara lain: ${ }^{34}$

- Darah lengkap (anemia,infeksi).

- Elektrolit, ureum, kreatinin serum (gangguan elektrolit atau gagal ginjal).

- Enzim jantung seperti CKMB dan atau troponin (infark miokard sebagai pencetus FA).

- Peptida natriuretik (BNP, N-terminal pro-BNP dan ANP) memiliki asosiasi dengan FA. Level plasma dari peptida natriuretik tersebut meningkat pada pasien dengan FA paroksismal maupun persisten, dan menurun kembali dengan cepat setelah restorasi irama sinus. ${ }^{37}$

- D-dimer (bila pasien memiliki risiko emboli paru).

- Fungsi tiroid (tirotoksikosis).

- Kadar digoksin (evaluasi level subterapeutik dan/atau toksisitas).

- Uji toksikologi atau level etanol.

\section{II.4.4. Elektrokardiogram $(\mathrm{EKG})^{34}$}

Temuan EKG biasanya dapat mengkonfirmasi diagnosis FA dan biasanya mencakup laju ventrikel bersifat ireguler dan tidak terdapat gelombang $\mathrm{P}$ yang jelas, digantikan oleh gelombang $F$ yang ireguler dan acak, diikuti oleh kompleks QRS yang ireguler pula.

Manifestasi EKG lainnya yang dapat menyertai FA antara lain:
- Laju jantung umumnya berkisar 110-140x/menit, tetapi jarang melebihi 160-170x/menit.

- Dapat ditemukan denyut dengan konduksi aberan (QRS Iebar) setelah siklus interval R-R panjangpendek (fenomena Ashman).

- Preeksitasi.

- Hipertrofi ventrikel kiri.

- Blok berkas cabang

- Tanda infark akut/lama.

Elektrokardiogram juga diperlukan untuk memonitor interval QT dan QRS dari pasien yang mendapatkan terapi antiaritmia untuk FA.

\section{II.4.5. Foto toraks}

Pemeriksaan foto toraks biasanya normal, tetapi kadang kadang dapat ditemukan bukti gagal jantung atau tanda-tanda patologi parenkim atau vaskular paru (misalnya emboli paru,pneumonia).

\section{II.4.6. Uji latih atau uji berjalan enam-menit}

Uji latih atau uji berjalan enam-menit dapat membantu menilai apakah strategi kendali laju sudah adekuat atau belum (target nadi $<110 \mathrm{x} /$ menit setelah berjalan 6-menit). Uji latih dapat menyingkirkan iskemia sebelum memberikan obat antiaritmia kelas $1 \mathrm{C}$ dan dapat digunakan juga untuk mereproduksi FA yang dicetuskan oleh aktivitas fisik. ${ }^{29}$

\section{II.4.7. Ekokardiografi}

Ekokardiografi transtorakal memiliki sensitivitas yang rendah dalam mendeteksi trombus di atrium kiri, dan ekokardiografi transesofageal adalah modalitas terpilih untuk tujuan ini.

Ekokardiografi transtorakal (ETT) terutama bermanfaat untuk:

- Evaluasi penyakit jantung katup

- Evaluasi ukuran atrium,ventrikel dan dimensi dinding

- Estimasi fungsi ventrikel dan evaluasi trombus ventrikel

- Estimasi tekanan sistolik paru (hipertensi pulmonal)

- Evaluasi penyakit perikardial

Ekokardiografi transesofageal (ETE) terutama bermanfaat untuk: 
- Trombus atrium kiri (terutama di AAK)

- Memandu kardioversi (bila terlihat trombus, kardioversi harus ditunda)

II.4.8. Computed tomography (CT) scan dan magnetic resonance imaging (MRI)

Pada pasien dengan hasil D-dimer positif, CT angiografi mungkin diperlukan untuk menyingkirkan emboli paru. Teknologi 3 dimensi seperti CT scan atau MRI seringkali berguna untuk mengevaluasi anatomi atrium bila direncanakan ablasi FA. Data pencitraan dapat diproses untuk menciptakan peta anatomis dari atrium kiri dan VP.

\section{II.4.9. Monitor Holter atau event recording}

Monitor Holter dan event recording dapat berguna untuk menegakkan diagnosis FA paroksismal, dimana pada saat presentasi, FA tidak terekam pada EKG. Selain itu, alat ini juga dapat digunakan untuk mengevaluasi dosis obat dalam kendali laju atau kendali irama. ${ }^{38}$

\section{II.4.10. Studi Elektrofisiologi}

Studi elektrofisiologi dapat membantu mengidentifikasi mekanisme takikardia QRS Iebar, aritmia predisposisi, atau penentuan situs ablasi kuratif.

\section{EVALUASI KLINIS/RENCANA TINDAK LANJUT}

Baru-baru ini dikenalkan skor simtom yang disebut skor EHRA (European Heart Rhythm Association). Skor ini adalah alat klinis sederhana yang dapat digunakan untuk menilai perkembangan gejala selama penanganan FA.

Tabel 2. Klasifikasi simtom terkait FA (skor EHRA). ${ }^{26}$

\begin{tabular}{|l|l|}
\multicolumn{1}{|c|}{ Kelas EHRA } & \multicolumn{1}{c|}{ Penjelasan } \\
\hline EHRA I & Tanpa gejala \\
\hline EHRA II & $\begin{array}{l}\text { Gejala ringan, aktivitas harian normal tidak } \\
\text { terpengaruh }\end{array}$ \\
\hline EHRA III & Gejala berat, aktivitas harian terganggu \\
\hline EHRA IV & Gejala melumpuhkan, aktivitas harian terhenti \\
\hline
\end{tabular}

$\mathrm{FA}=$ fibrilasi atrium, EHRA $=$ European Heart Rhytm Association
Skor klinis ini hanya memperhitungkan derajat gejala yang benar-benar disebabkan oleh FA,dan diharapkan skor tersebut dapat berkurang seiring dengan konversi ke irama sinus atau dengan kendali laju yang efektif.

Seorang ahli yang sedang menangani FA, tidak hanya harus melakukan penilaian dan pengobatan awal yang tepat, tetapi juga harus merencanakan tindak lanjut yang terstruktur. Pertimbangan yang penting selama tindak lanjut dari pasien FA antara lain sebagai berikut:

- Apakah terdapat perubahan profil risiko? (misalnya diabetes atau hipertensi baru)

- Apakah saat ini antikoagulan diperlukan (misalnya dengan kemunculan faktor risiko baru) atau antikoagulan dapat dihentikan? (misalnya pascakardioversi pada pasien dengan risiko tromboemboli rendah)

- Apakah simtom pasien membaik dengan terapi ? Bila tidak, apakah terapi lain harus dipertimbangkan?

- Apakah terdapat tanda-tanda proaritmia atau risiko proaritmia; bila demikian, haruskah dosis antiaritmia dikurangi atau diganti menjadi terapi lain?

- Apakah pendekatan kendali laju bekerja dengan baik; apakah target nadi saat istirahat dan saat aktivitas telah tercapai?

Pada kunjungan lanjutan, EKG 12 sadapan harus diambil untuk mendokumentasi irama dan laju jantung dan untuk menyelidiki progresivitas penyakit. Untuk mereka yang sudah diberikan terapi obat antiaritmia, adalah penting untuk menilai tanda-tanda dari EKG yang berpotensi proaritmia, seperti pemanjangan interval PR, QRS, atau QT, takikardia ventrikular atau jeda (pause).Bila terjadi perburukan simtom, maka tes darah, perekaman EKG jangka panjang dan ekokardiogram ulang dapat dipertimbangkan.

Pasien harus diberitahukan mengenai kelebihan dan kekurangan dari berbagai pilihan pengobatan, apakah itu antikoagulan, obat kendali laju, obat antiaritmia, atau terapi intervensional. ${ }^{2}$

\section{TATA LAKSANA}

\section{IV.1. Terapi antitrombotik pada FA}

IV.1.1. Penaksiran risiko stroke dan perdarahan Secara umum risiko stroke pada FA adalah 15\% per tahun 
yaitu berkisar 1,5\% pada kelompok usia 50 sampai 59 tahun dan meningkat hingga 23,5\% pada kelompok usia 80 sampai 89 tahun. ${ }^{39}$ Sedangkan rerata insiden stroke dan emboli sistemik lain adalah 5\% (berkisar 3-4\%). ${ }^{40}$ Oleh karena itu, penting sekali mengidentifikasi pasien FA yang memiliki risiko tinggi stroke dan tromboemboli. Akan tetapi pada praktik sehari-hari yang lebih penting justru identifikasi pasien FA yang benar-benar risiko rendah mengalami stroke agar risiko yang tidak perlu akibat pemberian antikoagulan dapat dihindari. Terapi antitrombotik tidak direkomendasikan pada pasien FA yang berusia $<65$ tahun dan FA sorangan karena keduanya termasuk benar-benar risiko rendah dengan tingkat kejadian stroke yang sangat rendah. ${ }^{41}$

Dengan demikian panduan stratifikasi risiko stroke pada pasien FA harus bersikap lebih inklusif terhadap berbagai faktor risiko stroke yang umum sehingga akan mencakup seluruh spektrum pasien FA. Skor $\mathrm{CHA}_{2} \mathrm{DS}_{2}$-VASc mencakup faktor-faktor risiko umum yang sering ditemukan pada praktik klinik sehari-hari. ${ }^{42-44} \mathrm{CHAD}_{2} \mathrm{DS}_{2}$-VASc masingmasing hurufnya merupakan awal dari kata tertentu yaitu Congestive heart failure, Hypertension, Age $\geq 75$ years (skor 2), Diabetes mellitus, Stroke history (skor 2), peripheral Vascular Disease, Age between 65 to 74 years, Sex Category (female). Riwayat gagal jantung bukan merupakan faktor risiko stroke, tetapi yang dimaksud dengan huruf "C" pada skor $\mathrm{CHA}_{2} \mathrm{DS}_{2}$-VASc adalah disfungsi ventrikel kiri sedang hingga berat (Left Ventricular Ejection Fraction/LVEF $\leq 40 \%$ ) atau pasien gagal jantung baru yang memerlukan rawat inap tanpa memandang nilai fraksi ejeksi. ${ }^{45}$ Hipertiroid juga bukan merupakan faktor risiko independen stroke pada analisis multivariat. ${ }^{46}$ Jenis kelamin perempuan meningkatkan risiko stroke secara independen, ${ }^{47}$ tetapi perempuan yang berusia $<65$ tahun dan menderita FA sorangan tidak meningkatkan risiko stroke sehingga tidak memerlukan terapi antikoagulan. ${ }^{47,48}$

Skor $\mathrm{CHA}_{2} \mathrm{DS}_{2}$-VASc sudah divalidasi pada berbagai studi kohor dan menunjukkan hasil yang lebih baik untuk mengidentifikasi pasien pasien FA yang benar-benar risiko rendah ${ }^{49,50}$ tetapi juga sebaik atau mungkin lebih baik dari skor $\mathrm{CHADS}_{2}$ untuk identifikasi pasien FA yang akan mengalami stroke dan tromboemboli. ${ }^{46,49,51}$ Skor $\mathrm{CHA}_{2} \mathrm{DS}_{2}$-VASc juga memperbaiki penaksiran risiko pada FA risiko rendah pascaablasi. ${ }^{52}$

Keputusan pemberian tromboprofilaksis perlu diseimbangkan dengan risiko perdarahan akibat antikoagulan, khususnya perdarahan intrakranial yang bersifat fatal atau menimbulkan disabilitas. Skor HAS-BLED yang merupakan kependekan dari Hypertension, Abnormal renal or liver function, history of Stroke, history of Bleeding, Labile INR value, Elderly dan antithrombotic Drugs and alcohol telah divalidasi pada banyak studi kohor berkorelasi baik dengan perdarahan intrakranial. ${ }^{46,53,54}$ Evaluasi risiko perdarahan pada setiap pasien FA harus dilakukan dan jika skor HAS-BLED 3 maka perlu perhatian khusus, pengawasan berkala dan upaya untuk mengoreksi faktor-faktor risiko yang dapat diubah. Skor HASBLED tidak digunakan untuk melakukan eksklusi pemakaian antikoagulan tetapi sebagai panduan sistematis dalam menaksir risiko perdarahan dan memikirkan faktor-faktor risiko yang dapat dikoreksi seperti tekanan darah yang belum terkontrol, penggunaan aspirin atau non-steroid anti-inflammatory drugs (NSAIDs), dsb. Hal yang penting untuk diperhatikan bahwa pada skor HAS-BLED yang

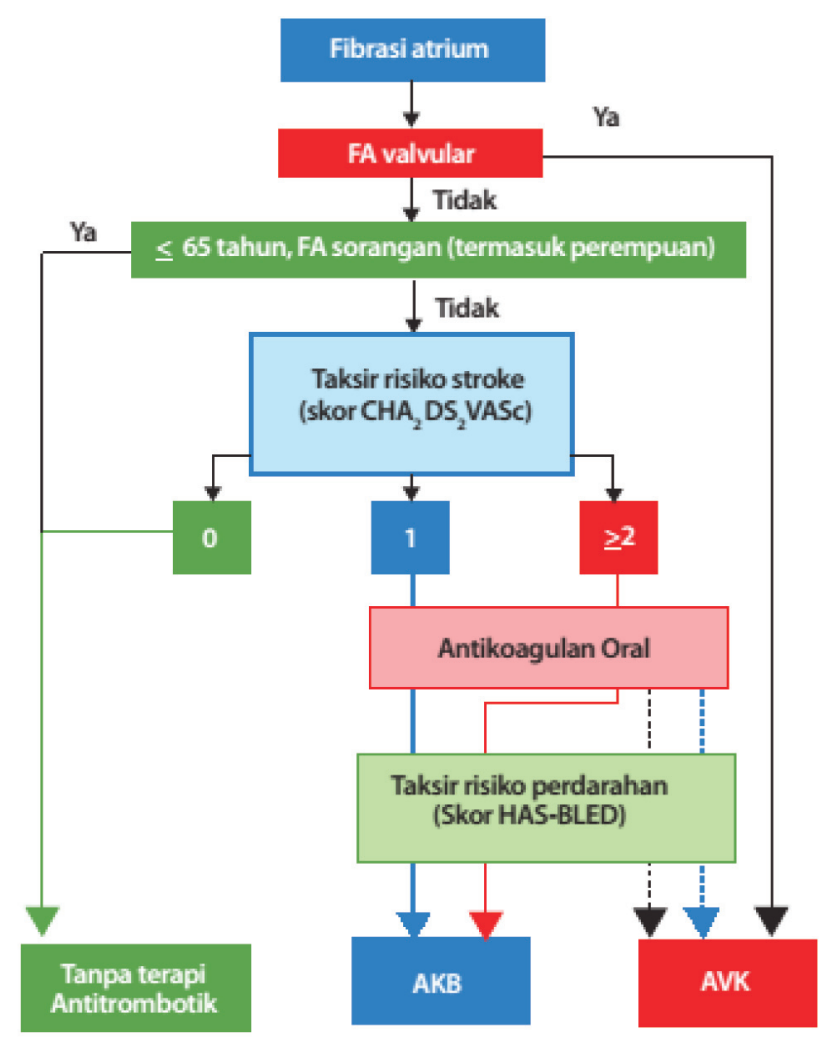

Gambar 7. Diagram pemilihan terapi antikoagulan AKB: antikoagulan oral baru, AVK: antagonis vitamin $\mathrm{K}$, garis padat: pilihan terbaik, garis putus-putus: pilihan alternatif (disadur dari referensi 41). 
sama, risiko perdarahan intrakranial dan perdarahan mayor lain dengan pemberian aspirin atau warfarin sama saja. ${ }^{46}$ Penggabungan skor $\mathrm{CHA}_{2} \mathrm{DS}_{2}$-VASc dan HAS-BLED sangat bermanfaat dalam keputusan tromboprofilaksis pada praktik sehari-hari.

\section{IV.1.2. Terapi Antitrombotik}

Terapi antitrombotik yang dipergunakan untuk prevensi stroke pada pasien FA meliputi antikoagulan (antagonis vitamin $\mathrm{K}$ dan antikoagulan baru), dan antiplatelet. Jenis antitrombotik lain yaitu trombolitik tidak digunakan untuk prevensi stroke pasien FA.

\section{Antagonis vitamin $K(A V K)$}

Antagonis vitamin K (warfarin atau coumadin) adalah obat antikoagulan yang paling banyak digunakan untuk pencegahan stroke pada FA. Telaah lima penelitian acak yang membandingkan AVK dengan plasebo mendapatkan penurunan insiden stroke iskemik dari $4,5 \%$ jadi $1,4 \%$ per tahun (relative risk reduction [RRR] 68\%; 95\% Cl, 5O\% s/d 79\%; $\mathrm{P}<0.001) .55$ Angka perdarahan mayor akibat AVK adalah $1,3 \%$ per tahun dibandingkan hanya $1 \%$ pada plasebo. Suatu analisismeta terhadap 26 studi baru-baru ini mendapatkan RRR 64\% (95\% Cl, 49\% s/d 74\%) untuk pencegahan sekunder stroke iskemik dan hemoragik. Angka absolute risk reduction (ARR) 2,7\% per tahun pada studi-studi prevensi primer dan $8,4 \%$ per tahun pada studi-studi prevensi sekunder. Terdapat peningkatan mortalitas signifikan dengan AVK yaitu ARR 1,6\% per tahun. Bukti tambahan menunjukkan bahwa pencegahan stroke oleh AVK hanya efektif bila time in therapeutic range (TTR) baik yaitu $>70 \%$. TTR adalah proporsi waktu ketika INR 2-3 tercapai dibandingkan keseluruhan lama waktu mengkonsumsi AVK.5657

Oleh karena itu, upaya pengaturan dosis yang terus-menerus harus dilakukan untuk memperoleh nilai target INR 2-3. Kesulitan pemakaian AVK di Indonesia ialah tidak tersedianya fasilitas pemeriksaan INR di daerah-daerah perifer.Dalam kaitan ini perlu juga diperhatikan adanya faktor genetik pada etnis Indonesia yang berkaitan dengan sensitivitas individu terhadap warfarin. ${ }^{58}$

\section{Antikoagulan Baru (AKB)}

Saat ini terdapat 3 jenis AKB yang bukan merupakan AVK di pasaran Indonesia, yaitu dabigatran, rivaroxaban, dan apixaban. Dabigatran bekerja dengan cara menghambat langsung trombin sedangkan rivaroxaban dan apixaban keduanya bekerja dengan cara menghambat faktor Xa.

\section{- Dabigatran Etexilate}

Studi RE-LY (Randomized Evaluation of Long-term anticoagulant therap $\boldsymbol{Y}$ with dabigatran etexilate), ${ }^{59}$ suatu studi acak dengan tiga lengan yaitu membandingkan 2 jenis dosis dabigatran etexilate $[110 \mathrm{mg}$ b.i.d. (D110) atau $150 \mathrm{mg}$ b.i.d. (D150)] dengan adjusted dose warfarin (target INR of 2-3). Untuk primary efficacy endpoint berupa stroke dan emboli sistemik, D150 lebih superior dari warfarin, tanpa perbedaan signifikan dalam hal primary safety endpoint berupa perdarahan mayor. D110 non-inferior terhadap warfarin, dengan $20 \%$ lebih sedikit kejadian perdarahan mayor. Angka stroke hemoragik dan perdarahan intracranial lebih rendah pada kedua dosis dabigatran tetapi perdarahan gastrointestinal meningkat bermakna dengan D150. Terdapat penurunan signifikan stroke iskemik, terdapat kecenderungan penurunan mortalitas segala sebab $(\mathrm{P}=0,051)$ dan penurunan signifikan mortalitas vaskular $(\mathrm{P}=0,04)$ dengan $\mathrm{D} 150$. Angka berhenti minum obat lebih tinggi pada D150 (20,7\%) dan D110 (21,2\%), dibanding dengan warfarin $(16,6 \%)$ pada pengamatan 2 tahun. Efikasi dan keamanan dabigatran konsisten pada seluruh strata skor $\mathrm{CHADS}_{2}$ dan sama efeknya baikpada bekas pemakai maupun belum pernah memakai AVK. ${ }^{60}$ Berdasarkan hasil studi RE-LY, dabigatran etexilate telah disetujui Food and Drug Administration (FDA) dan European Medicines Agency (EMA), juga oleh beberapa badan otoritas obat dan makanan berbagai negara lain, untuk pencegahan stroke dan tromboemboli. European Medicines Agency menetapkan indikasi pemakaian dabigatran untuk FA non-valvular dengan paling tidak satu faktor risiko berikut: riwayat stroke, transient ischaemic attack (TIA) atau emboli sistemik; LVEF $<40 \%$; gagal jantung simtomatik; dan usia 75 tahun atau 65 tahun tetapi disertai salah satu dari diabetes, penyakit jantung koroner atau hipertensi. FDA menyetujui dosis 150 $\mathrm{mg}$ b.i.d., dan dosis $75 \mathrm{mg}$ b.i.d. bila terjadi gangguan ginjal berat, sedangkan EMA menyetujui baikdosis 110 mg b.i.d. maupun $150 \mathrm{mg}$ b.i.d.

\section{- Rivaroxaban}

Studi buta ganda ROCKET-AF ${ }^{61}$ terhadap 14264 pasien FA risiko tinggi yang diberikan rivaroxaban 
$20 \mathrm{mg}$ o.d. (15 mg o.d. bila kreatinin klirens hitung $30-49 \mathrm{ml} / \mathrm{min}$ ) dibandingkan dengan warfarin. Subjek pada studi ini mempunyai risiko yang lebih tinggi untuk stroke dibandingkan studi $\mathrm{AKB}$ lain tetapi rerata TTR hanya 55\% yang lebih rendah dibanding semua studi AKB lain. Didapatkan hasil bahwa rivaroxaban non-inferior dibanding warfarin untuk primary endpoint berupa stroke dan emboli sistemik. Tidak terdapat penurunan angka mortalitas atau stroke iskemik tetapi terdapat penurunan bermakna stroke hemoragik dan perdarahan intrakranial. Tidak ada perbedaan pada primary safety endpoint yaitu gabungan perdarahan mayor dan perdarahan yang relevan secara klinis tetapi terdapat penurunan perdarahan fatal pada kelompok rivaroxaban. Lebih sering terjadi diskontinuitas terapi pada rivaroxaban $(23,9 \%)$ dibanding warfarin $(22,4 \%)$. Rivaroxaban juga telah disetujui oleh FDA dan EMA untuk prevensi stroke pada FA non-valvular, sebagaimana juga di beberapa negara lain.

\section{- Apixaban}

Studi AVERROES ${ }^{62}$ terhadap 5599 pasien FA yang tidak cocok atau tidak ingin mendapat terapi AVK diberikan apixaban $5 \mathrm{mg}$ b.i.d. dengan penyesuaian dosis jadi $2,5 \mathrm{mg}$ b.i.d. bila usia 80 tahun, berat badan $\leq 60 \mathrm{~kg}$ atau kreatinin serum $\geq 1,5 \mathrm{mg} / \mathrm{dl}$ $(133 \mathrm{mmol} / \mathrm{L})]$ atau diberikan aspirin $(81-324 \mathrm{mg} /$ hari, dengan $91 \%$ minum $\leq 162 \mathrm{mg} /$ hari). Setelah masa pengamatan 1,1 tahun, studi dihentikan lebih awal karena didapatkan penurunan signifikan 55\% pada primary endpoint berupa stroke atau emboli sistemik pada kelompok apixaban dibanding aspirin, tanpa perbedaan kejadian perdarahan mayor dan intrakranial. Apixaban ditoleransi lebih baik daripada aspirin dengan angka penghentian minum obat $17,9 \%$ dibandingkan aspirin yang mencapai $20,5 \%$ $(\mathrm{p}=0,03)$.

Sementara itu studi ARISTOTLE ${ }^{63}$ membandingkan apixaban [5 mg b.i.d. dengan penyesuaian dosis jadi $2,5 \mathrm{mg}$ b.i.d bila 80 tahun, berat badan $\leq 60 \mathrm{~kg}$ atau dengan kreatinin serum $\geq 1,5 \mathrm{mg} / \mathrm{dl}$ (133mmoi/L)] dengan warfarin dosis disesuaikan untuk memperoleh nilai INR 2-3 pada 18201 pasien FA non-valvular. Terdapat penurunan bermakna primary efficacy outcome berupa stroke atau emboli sistemik hingga $21 \%$ pada kelompok apixaban dibanding warfarin, penurunan $31 \%$ kejadian perdarahan mayor dan penurunan signifikan $11 \%$ mortalitas segala sebab (tetapi bukan mortalitas kardiovaskular). Angka kejadian stroke hemoragik dan perdarahan intrakranial lebih rendah secara bermakna pada kelompok apixaban tetapi tidak demikian untuk stroke iskemik. Apixaban ditoleransi lebih baik daripada warfarin dengan lebih sedikit diskontinuitas dini $(25,3 \%$ vs $27,5 \%)$. Apixaban juga sudah mendapat persetujuan EMA dan FDA untuk indikasi prevensi stroke pada FA non-valvular.

\section{IV.1.3. Penutupan aurikel atrium kiri (AAK)}

Aurikel atrium kiri merupakan tempat utama terbentuknya trombus yang bila lepas dapat menyebabkan stroke iskemik pada FA. Dikatakan hampir $90 \%$ trombus pada FA terbentuk di AAK. ${ }^{24}$ Angka stroke yang rendah didapatkan pada pasien yang dilakukan pemotongan AAK pada saat operasi jantung. Baru-baru ini suatu teknik invasif epikard dan teknik intervensi transeptal telah dikembangkan untuk menutup AAK. ${ }^{64-66}$ Teknik ini dapat merupakan alternatif terhadap antikoagulan oral bagi pasien FA dengan risiko tinggi stroke tetapi kontraindikasi pemberian antikoagulan oral jangka lama.

Saat ini dua jenis alat penutup AAK yang dapat mengembang sendiri yaitu WATCHMAN (Boston Scientific, Natick, MA, USA) dan Amplatzer Cardiac Plug (St. Jude Medical, St Paul, MN, USA), yang ditempatkan di AAK secara transeptal sudah mulai dipakai di Eropa. Studi WATCHMAN LAA system for embolic PROTECTion in patients with Atrial Fibrillation (PROTECT AF) melakukan randomisasi 707 pasien FA untuk membandingkan pemakaian WATCHMAN dengan warfarin (nilai INR 2-3; n kontrol = 244). M Pasien yang dipasang WATCHMAN diberikan juga warfarin selama 45 hari pascaprosedur kemudian dilanjutkan dengan dual antiplatelet selama 6 bulan lalu aspirin saja sebagai terapi jangka panjang. Angka primary efficacy event (gabungan antara stroke, kematian kardiovaskular, dan emboli sistemik) pada kelompokAAK noninferior dibandingkan kelompok warfarin. Terdapat angka efek samping yang tinggi pada kelompok AAK terutama akibat komplikasi periprosedur. Tetapi kejadian komplikasi makin berkurang dengan learning curve. ${ }^{67}$ Studi lainya,PREVAIL (Prospective $\boldsymbol{R}$ andomized $\boldsymbol{E V A l u a t i o n}$ of the Watchman LM closure device In patients with atrial fibrillation vs. Long-term warfarin therapy) menunjukkan penutupan AAK memakai WATCHMAN makin aman bahkan jika 
dilakukan oleh seorang operator pemula sekalipun. Sementara itu penutupan AAK memakai Amplatzer Cardiac Plug dapat dilakukan dengan angka kesuksesan 96\% dengan angka komplikasi serius mencapai 7\%. ${ }^{65}$ Suatu studi prospektif acak Amplatzer Cardiac Plug Trial saat ini sedang berlangsung. Sekalipun konsep penutupan AAK masuk akal tetapi bukti-bukti yang ada belum cukup untuk direkomendasikan terhadap setiap pasien FA tetapi hanya terbatas bagi pasien yang kontraindikasi pemakaian antikoagulan oral jangka lama. Hal lain yang perlu diperhatikan bahwa pasca-pemasangan penutup AAK masih diperlukan konsumsi aspirin seumur hidup sementara itu risiko perdarahan karena aspirin cukup signifikan sehingga hal ini akan menjadi faktor yang melemahkan pemakaian penutup AAK.

\section{IV.1.4. Panduan praktis obat antikoagulan}

Obat antikoagulan baru terbukti non-inferior dibanding warfarin dengan tingkat keamanan yang lebih baik. Atas dasar ini AKB lebih disarankan daripada warfarin pada mayoritas pasien FA non valvular.Karena belum ada perbandingan langsung antar berbagai AKB maka sulit untuk mengatakan mana yang paling baik. Perbandingan tak langsung tidak menunjukkan perbedaan yang kentara efikasi antar berbagai AKB itu,tetapi dalam hal angka perdarahan mayor dabigatran $110 \mathrm{mg}$ b.i.d dan apixaban lebih rendah. ${ }^{68}$ Pertimbangkan ciri-ciri pasien, toleransi obat, dan biaya dalam memilih antikoagulan. Data studi cost effective dabigatran pada beberapa jenis layanan kesehatan menunjukkan dabigatran costeffective untuk kebanyakan pasien, ${ }^{69,70}$ kecuali pada pasien yang sangat baik kontrol INRnya. ${ }^{41}$ Semua AKB tidak memiliki antidot yang spesifik.

Berdasarkan survei nasional di Denmark ${ }^{71}$ untuk melihat keseimbangan antara stroke dan perdarahan intrakranial didapatkan bila skor $\mathrm{CHA}_{2} \mathrm{DS}_{2}$-VASc 1 hanya apixaban dan kedua dosis dabigatran $(110 \mathrm{mg}$ b.i.d.dan $150 \mathrm{mg}$ b.i.d.) yang memberikan manfaat klinis yang lebih baik dari warfarin; tetapi bila skor $\mathrm{CHA}_{2} \mathrm{DS}_{2}$-VASc $\geq 2$ seluruh AKB lebih superior dibanding warfarin. Bila akan mengubah dari AVK ke AKB maka harus dicapai nilai INR $\leq 2$ terlebih dahulu. Sebaliknya,bila akan mengganti dari AKB ke AVK maka AVK harus dimulai secara tumpang tindih dengan $\mathrm{AKB}$ dalam periode yang tergantung pada jenis $\mathrm{AKB}$ dan fungsi ginjal. AKB dihentikan ketika INR $>2$. Misalnya, bila memakai dabigatran dibutuhkan tumpang tindih AVK 2-3 hari karena awitan kerja AVK membutuhkan beberapa hari untuk mencapai efek terapi. Penaksiran fungsi ginjal (memakai klirens kreatinin hitung) wajib dilakukan pada pemberian AKB karena seluruh obat tersebut sedikit banyak diekskresi melalui ginjal. Pada pasien dengan nilai awal klirens kreatinin normal $(\geq 80 \mathrm{~mL} / \mathrm{min})$ atau gangguan ginjal ringan (klirens kreatinin 50-79 mL/ min) dilakukan pemeriksaan klirens kreatinin 1 kali per tahun sedangkan pada pasien dengan gangguan ginjal sedang (klirens kreatinin 30-49 mL/min) maka dianjurkan pemeriksaan klirens kreatinin 2-3 kali per tahun.Dabigatran dapat menyebabkan dispepsia yang dapat dihindari dengan cara minum obat berbarengan dengan makanan atau dengan pemberian inhibitor pompa proton. Semua AKB tidak direkomendasikan pada gangguan ginjal berat (klirens kreatinin $<30 \mathrm{~mL}$ / $\min ) .{ }^{41}$

Berbeda dengan AVK, AKB tidak memerlukan penyesuaian dosis. Walaupun terdapat tes koagulasi non-spesifik untuk memeriksa efek antikoagulansi $\mathrm{AKB}$, tetapi hal itu tidak dipergunakan untuk penyesuaian dosis. Sebagai contoh, Ecarin clotting time

Tabel 3. Pilihan terapi pada pasien dengan penyakit ginjal kronik dan faktor risiko stroke $\left(\mathrm{CHADS}_{2} \geq 1\right) .{ }^{72}$

\begin{tabular}{|c|c|c|c|c|}
\hline $\begin{array}{l}\text { Laju filtrasi } \\
\text { glomerulus } \\
\text { (LFG), } \\
\text { dalam mL/ } \\
\text { menit }\end{array}$ & Warfarin & Dabigatran & Rivaroxoban & Apixaban* \\
\hline LFG $\geq 60$ & Target INR 2-3 & $\begin{array}{l}150 \text { mg b.i.d. atau } \\
110 \mathrm{mg} \text { b.i.d. }\end{array}$ & $\begin{array}{l}20 \mathrm{mg} \text { per } \\
\text { hari }\end{array}$ & 5 mg b.i.d. \\
\hline LFG 50-59 & Target INR 2-3 & $\begin{array}{l}150 \text { mg b.i.d. atau } \\
110 \mathrm{mg} \text { b.i.d. }\end{array}$ & $\begin{array}{l}20 \mathrm{mg} \text { per } \\
\text { hari }\end{array}$ & 5 mg b.i.d. \\
\hline LFG 30-49 & Target INR 2-3 & $\begin{array}{l}150 \mathrm{mg} \text { b.i.d. atau } \\
110 \mathrm{mg} \text { b.i.d. }\end{array}$ & $\begin{array}{l}15 \mathrm{mg} \text { per } \\
\text { hari }\end{array}$ & $\begin{array}{l}5 \mathrm{mg} \text { b.i.d. (hanya } \\
\text { untuk LFG > } 25 \\
\mathrm{~mL} / \text { menit) } \\
\text { Pertimbangkan } \\
2,5 \text { mg b.i.d. }^{+}\end{array}$ \\
\hline $\begin{array}{l}\text { LFG 15- } \\
29 \text { (tidak } \\
\text { menjalani } \\
\text { dialisis) }\end{array}$ & $\begin{array}{l}\text { Tidak ada data } \\
\text { studi acak } \\
\text { terkontrol }{ }^{*}\end{array}$ & $\begin{array}{l}\text { Tidak ada data studi } \\
\text { acak terkontrol }{ }^{5}\end{array}$ & $\begin{array}{l}\text { Tidak } \\
\text { ada data } \\
\text { studi acak } \\
\text { terkontrol" }\end{array}$ & $\begin{array}{l}5 \mathrm{mg} \text { b.i.d. (hanya } \\
\text { untuk LFG }>25 \\
\mathrm{~mL} / \text { menit) } \\
\text { Pertimbangkan } \\
2,5 \mathrm{mg} \text { b.i.d. }{ }^{+}\end{array}$ \\
\hline $\begin{array}{l}\text { LFG }<15 \\
\text { (menjalani } \\
\text { dialisis) }\end{array}$ & $\begin{array}{l}\text { Tidak ada data } \\
\text { studi acak } \\
\text { terkontrol }{ }^{*}\end{array}$ & $\begin{array}{l}\text { Tidak ada data studi } \\
\text { acak terkontrol" }\end{array}$ & $\begin{array}{l}\text { Tidak } \\
\text { ada data } \\
\text { studi acak } \\
\text { terkontrol" }\end{array}$ & $\begin{array}{l}\text { Tidak ada data } \\
\text { studi acak } \\
\text { terkontrol }\end{array}$ \\
\hline
\end{tabular}

b.i.d.: dua kali sehari, $\mathrm{CHADS}_{2}$ : Chronic Heart Failure, Hypertension, Age >75, Diabetes Mellitus, and Prior Stroke or Transient Ischemic Attack score, LFG: laju filtrasi glomerulus, INR: international normalized ratio.

* Belum disetujui oleh Kesehatan Kanada.

$\dagger$ Pertimbangkan Apixaban 2,5 mg PO b.i.d bila LFG $\leq 25 \mathrm{~mL} / \mathrm{menit}$, terutama bila usia $>80$ atau berat badan $<60 \mathrm{~kg}$.

¥Warfarin dengan dosis yang disesuaikan sudah digunakan, akan tetapi data observasional mengenai keamanan pemakaian dan efikasi bertentangan.

$\S$ Studi model menunjukkan bahwa dabigatran $75 \mathrm{mg}$ b.i.d. mungkin aman untuk digunakan pada pasien dengan LFG $15-29 \mathrm{~mL} /$ menit, akan tetapi hal ini belum divalidasi dalam kohor prospektif.

I Tidak terdapat studi terpublikasi yang mendukung penggunaan dosis pada tingkat fungsi ginjal ini; keterangan pada produk menyatakan obat ini dikontraindikasikan pada tingkat fungsi ginjal ini. 
dan thrombin time, yang menggambarkan inhibisi langsung trombin, digunakan untuk pemeriksaan efek dabigatran, sedangkan pengujian anti-Xa dapat dipergunakan untuk memeriksa efek antikoagulan rivaroxaban dan apixaban. ${ }^{73}$

Antikoagulan baru tidak memiliki antidot spesifik oleh karena itu bila terjadi perdarahan maka tata laksananya terutama bersifat suportif dengan pertimbangan bahwa AKB memiliki waktu paruh yang pendek (Gambar 8 ). ${ }^{74,75}$

Tata laksana peribedah pada pasien dengan antikoagulan oral merupakan suatu area yang memerlukan pertimbangan khusus. ${ }^{74,76}$ Dabigatran memiliki awitan dan offset yang cepat, sehingga tidak memerlukan terapi antara low molecular weight heparin (LMWH). ${ }^{77}$ Pascabedah AKB dapat segera diberikan lagi setelah hemostasis efektif tercapai. Efek $\mathrm{AKB}$ sudah akan diperoleh dalam beberapa jam saja

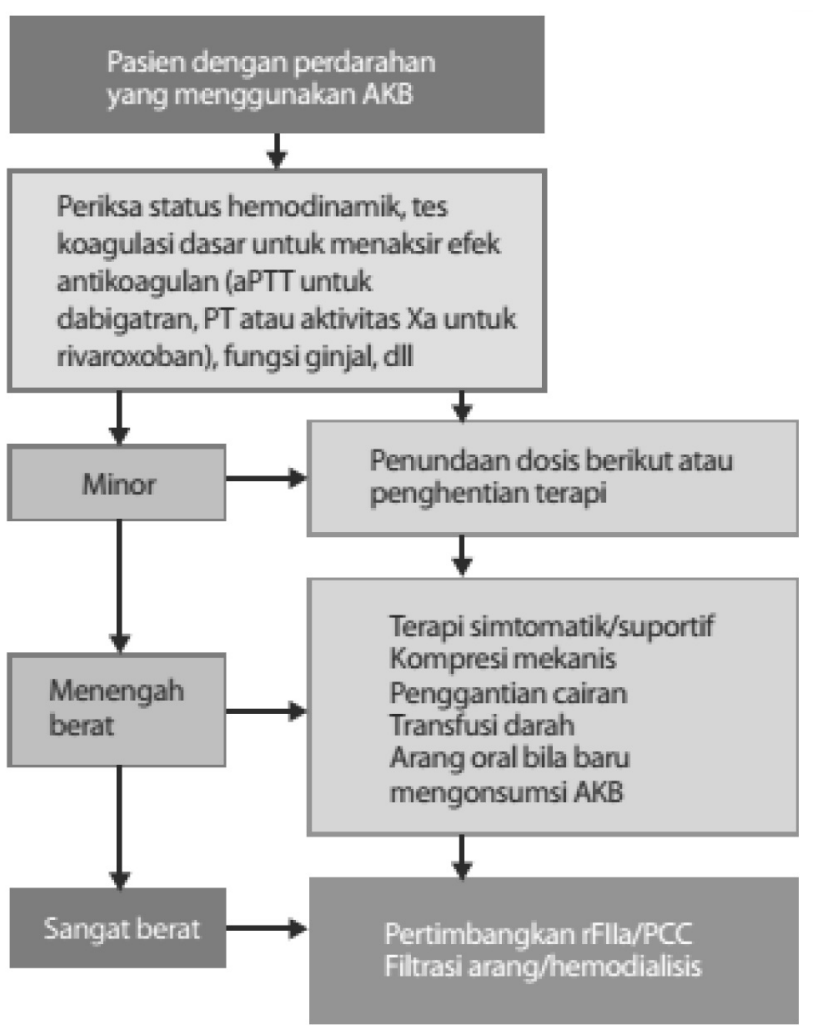

Gambar 8. Tata laksana perdarahan akibat Anti Koagulan Baru (AKB). aPTT $=$ activated partial thromboplastin time, $\mathrm{PT}=$ prothrombin time, $\mathrm{rFIIa}=$ recombinant factor $\mathrm{IIa}, \mathrm{PCC}=$ prothrombin complex concentrate (disadur dari referensi 41). pasca pemberian dosis pertama. Kardioversi elektif dapat dilakukan dengan aman setelah diberikan dabigatran selama 3 minggu dan dilanjutkan 4 minggu kemudian pascakardioversi. ${ }^{78}$ Kejadian komplikasi kardioversi elektif dengan atau tanpa panduan ETE tidak berbeda. ${ }^{26}$

Belum ada data yang kuat tentang perbedaan efek penghentian sementara $\mathrm{AKB}$ pada pasien FA yang akan menjalani ablasi. Ablasi ketika masih dalam AKB bisa jadi secara teoritis akan menimbulkan risiko jika terjadi perdarahan mayor karena tidak adanya antidot spesifik. ${ }^{79}$

\section{2. Tata Laksana pada Fase Akut}

\section{IV.2.1. Kendali laju fase akut}

Pada pasien dengan hemodinamik stabil dapat diberikan obat yang dapat mengontrol respon ventrikel. Pemberian penyekat beta atau antagonis kanal kalsium non-dihidropiridin oral dapat digunakan pada pasien dengan hemodinamik stabil. Antagonis kanal kalsium non-dihidropiridin hanya boleh dipakai pada pasien dengan fungsi sistolik ventrikel yang masih baik. Obat intravena mempunyai respon yang lebih cepat untuk

Tabel 4. Terapi antitrombotik di berbagai tingkat layanan kesehatan.

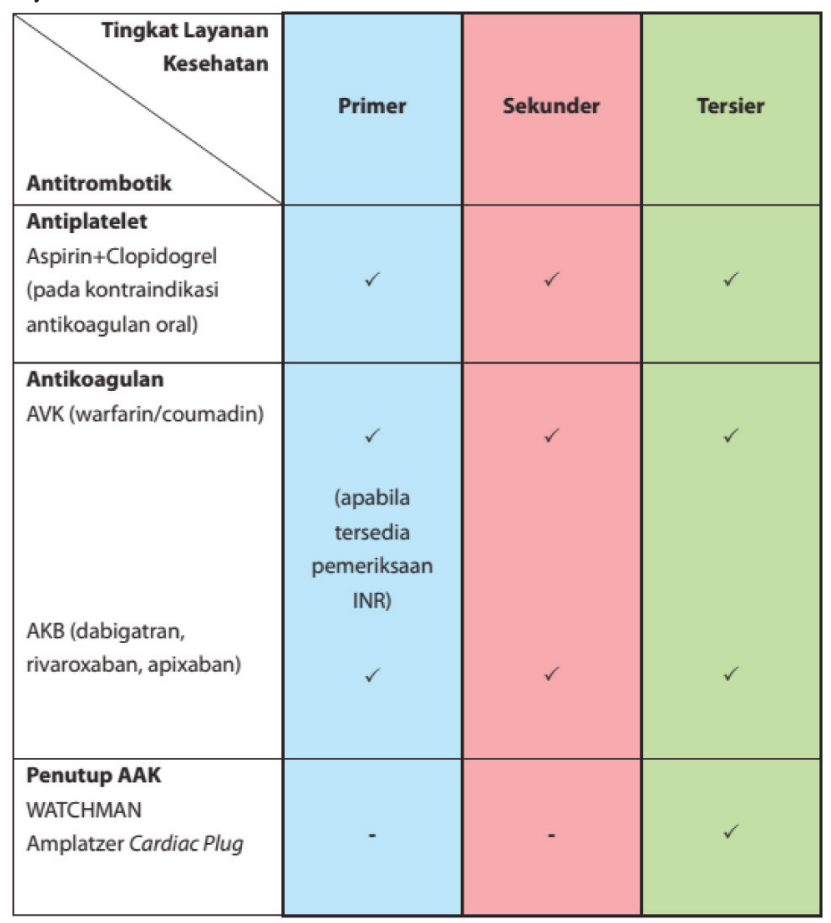


mengontrol respon irama ventrikel. Digoksin atau amiodaron direkomendasikan untuk mengontrol laju ventrikel pada pasien dengan FA dan gagal jantung atau adanya hipotensi. Namun pada FA dengan preeksitasi obat terpilih adalah antiaritmia kelas I (propafenon, disopiramid, mexiletine) atau amiodaron. Obat yang menghambat NAV tidak boleh digunakan pada kondisi FA dengan preeksitasi karena dapat menyebabkan aritmia letal. Pada fase akut, target laju jantung adalah $80-100 \mathrm{kpm} .{ }^{41}$ Rekomendasi obat intravena yang dapat digunakan pada kondisi akut dapat dilihat di tabel 5.80

Pada layanan kesehatan primer yang jauh dari pusat rujukan sekunder/tersier, untuk sementara kendali laju dapat dilakukan dengan pemberian obat antiaritmia oral. Diharapkan laju jantung akan menurun dalam waktu 1-3 jam setelah pemberian antagonis kanal kalsium (diltiazem $30 \mathrm{mg}$ atau verapamil $80 \mathrm{mg}$ ), penyekat beta (propanolol 20-40 mg, bisoprolol $5 \mathrm{mg}$, atau metoprolol $50 \mathrm{mg}$ ). ${ }^{81,83}$ Dalam hal ini penting diperhatikan untuk menyingkirkan adanya riwayat dan gejala gagal jantung. Kendali laju yang efektif tetap harus dengan pemberian obat antiaritmia intravena di layanan kesehatan sekunder/tersier.

Fibrilasi atrium dengan respon irama ventrikel yang lambat, biasanya membaik dengan pemberian atropin (mulai $0,5 \mathrm{mg}$ intravena). Bila dengan pemberian atropin pasien masih simtomatik, dapat dilakukan tindakan kardioversi atau pemasangan pacu jantung sementara. ${ }^{41}$

\section{IV.2.2. Kendali irama fase akut}

Respon irama ventrikel yang terlalu cepat akan menyebabkan gangguan hemodinamik pada pasien FA. Pasien yang mengalami hemodinamik tidak stabil akibat FA harus segera dilakukan kardioversi elektrik untuk mengembalikan irama sinus. ${ }^{84}$ Pasien yang masih simtomatik dengan gangguan hemodinamik meskipun strategi kendali laju telah optimal, dapat dilakukan kardioversi farmakologis dengan obat antiaritmia intravena atau kardioversi elektrik. Saat pemberian obat antiaritmia intravena pasien harus dimonitor untuk kemungkinan kejadian proaritmia akibat obat, disfungsi nodus sinoatrial (henti sinus atau jeda sinus) atau blok atrioventrikular. Obat intravena untuk kardioversi farmakologis yang tersedia di Indonesia adalah amiodaron. Kardioversi dengan amiodaron terjadi beberapa jam kemudian setelah pemberian. ${ }^{41}$
Tabel 5. Terapi intravena untuk kendali laju fase akut. ${ }^{84}$

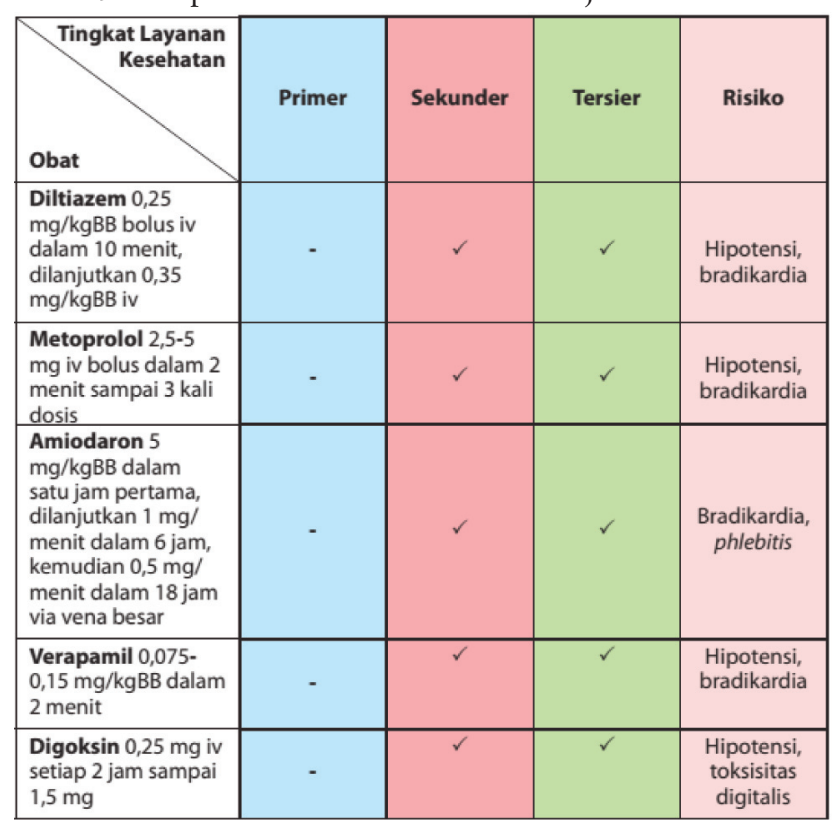

iv: intravena

\section{IV.2.3. Terapi pil dalam saku (pildaku)}

Pemberian propafenon oral (450-600 mg) dapat mengonversi irama FA menjadi irama sinus. Efektivitas propafenon oral tersebut mencapai 45\% dalam 3 jam. Strategi terapi ini dapat dipilih pada pasien dengan simtom yang berat dan FA jarang (sekali dalam sebulan). ${ }^{41,84}$ Oleh karena itu, propafenon (450-600 mg) dapat dibawa dalam saku untuk dipergunakan sewaktu-waktu pasien memerlukan (pil dalam saku - pildaku).

\section{IV.3. Tata Laksana Jangka Panjang}

\section{IV.3.1. Strategi terapi FA}

Tata laksana FA mencakup beberapa hal yaitu terapi optimal penyakit kardiovaskular yang menyertai, pemilihan strategi kendali irama atau kendali laju, pencegahan tromboemboli, dan terapi upstream. ${ }^{41}$

Studi terbesar tentang pemilihan strategi terapi FA adalah studi The Atrial Fibrillation Follow-up Investigation of Rhythm Management (AFFIRM) yang melibatkan 4060 pasien. Studi ini menunjukkan tidak terdapat perbedaan mortalitas secara umum antara pemilihan strategi kendali laju atau kendali irama pada pasien FA. ${ }^{6}$ Beberapa studi lain juga 
telah dilakukan dan didapatkan bahwa kendali laju tidak inferior dibandingkan dengan kendali irama untuk pencegahan mortalitas dan morbiditas kardiovaskular. ${ }^{41,85}$ Namun kebanyakan studi tersebut mengeluarkan pasien dengan usia muda $(<65$ tahun) dengan FA persisten, pasien tanpa kelainan jantung struktural,dan pasien dengan gagal jantung berat. Pada pasien tersebut, pemilihan strategi kendali irama masih dapat dipertimbangkan. Secara umum strategi kendali laju dihubungan dengan angka perawatan rumah sakit yang lebih rendah, efek samping obat antiaritmia yang lebih minimal dan biaya yang lebih ringan dibandingan dengan strategi kendali irama. ${ }^{86}$

\section{IV.3.2. Kendali laju jangka panjang}

Simtom akibat FA adalah hal penting untuk menentukan pemilihan kendali laju atau irama. Faktor lain yang juga mempengaruhi adalah FA yang sudah lama, usia tua, penyakit kardiovaskular berat, penyakit lain yang menyertai,dan besarnya atrium kiri. ${ }^{85}$

Pada pasien dengan FA simtomatik yang sudah terjadi lama, terapi yang dipilih adalah kendali laju. Namun, apabila pasien masih ada keluhan dengan strategi kendali laju,kendali irama dapat menjadi strategi terapi selanjutnya. ${ }^{41,85,86}$

Kendali laju dipertimbangkan sebagai terapi awal pada pasien usia tua dan keluhan minimal (skor EHRA 1). Kendali irama direkomendasikan pada pasien yang masih simtomatik (skor EHRA 2) meskipun telah dilakukan kendali laju optimal.

Beberapa indikasi pemilihan strategi terapi pada persisten FA dapat dilihat di tabel 6.

Kendali laju yang optimal dapat menyebabkan keluhan berkurang dan memperbaiki hemodinamik dengan memperpanjang waktu pengisian ventrikel dan mencegah kardiomiopati akibat takikardia. Kendali laju dapat dilakukan secara longgar atau ketat. Studi RAte Control Efficacy in permanent atrial fibrillation (RACE) II menunjukkan bahwa kendali laju ketat tidak lebih baik dari kendali laju longgar. ${ }^{87}$

Pada kendali laju longgar,target terapi adalah respon ventrikel $<110 \mathrm{kpm}$ saat istirahat. Apabila dengan target ini pasien masih merasakan keluhan, dianjurkan untuk melakukan kendali laju ketat yaitu dengan target laju saat istirahat $<80 \mathrm{kpm}$. Evaluasi monitor Holter dapat dilakukan untuk menilai terapi dan memantau ada tidaknya bradikardia. ${ }^{41}$

Penyekat beta direkomendasikan sebagai terapi pilihan pertama pada pasien FA dengan gagal jantung dan fraksi ejeksi yang rendah atau pasien dengan riwayat infark miokard. ${ }^{41,84}$ Apabila monoterapi tidak cukup, dapat ditambahkan digoksin untuk kendali laju. ${ }^{41}$ Digoksin tidak dianjurkan untuk terapi awal pada pasien FA yang aktif, dan sebaiknya hanya diberikan pada pasien gagaI jantung sistolik yang tidak memiliki aktivitas tinggi. Hal ini disebabkan karena digoksin hanya bekerja pada parasimpatis. Amiodaron untuk kendali laju hanya diberikan apabila obat lain tidak optimal untuk pasien. ${ }^{84}$

Tabel 6. Indikasi kendali laju dan kendali irama pada persisten FA. ${ }^{84}$

\begin{tabular}{|c|c|}
\hline $\begin{array}{c}\text { Strategi kontrol laju } \\
\text { Dipilih sebagai penanganan } \\
\text { awal pada: }\end{array}$ & $\begin{array}{c}\text { Strategi kontrol irama } \\
\text { Dipilih sebagai penanganan awal } \\
\text { pada: }\end{array}$ \\
\hline Usia $>65$ tahun & Usia <65 tahun \\
\hline $\begin{array}{c}\text { Dengan penyakit arteri koroner } \\
\text { Kontraindikasi obat-obatan } \\
\text { antiaritmia }\end{array}$ & $\begin{array}{c}\text { Simtom yang berhubungan dengan } \\
\text { aritmia dan tidak dapat ditoleransi }\end{array}$ \\
\hline Tidak cocok untuk kardioversi & Pertama kali mengalami FA sorangan \\
\hline Tanpa gagal jantung kongestif & Dengan gagal jantung kongestif \\
\hline
\end{tabular}

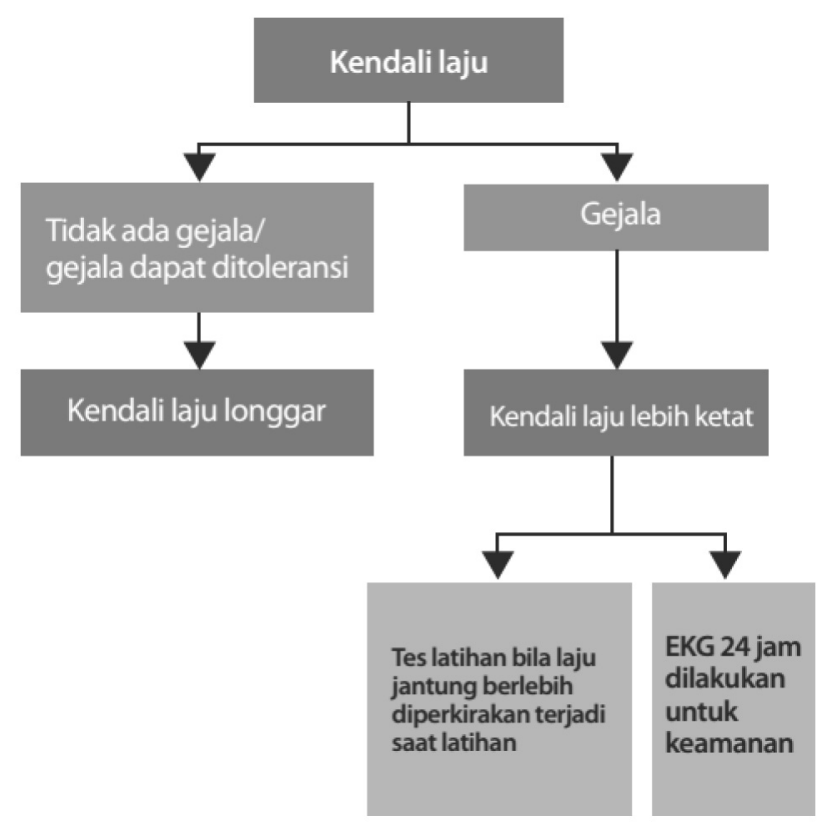

Gambar 9. Kendali laju jantung optimal (disadur dari referensi 2). 
Tabel 7 menunjukkan beberapa obat yang dapat digunakan untuk kendali laju.

\section{IV.3.3. Kendali irama jangka panjang}

Tujuan utama strategi kendali irama adalah mengurangi simtom. Strategi ini dipilih pada pasien yang masih mengalami simtom meskipun terapi kendali laju telah dilakukan secara optimal. ${ }^{84,85}$ Pilihan pertama untuk terapi dengan kendali irama adalah memakai obat antiaritmia. ${ }^{84}$ Pengubahan irama FA ke irama sinus (kardioversi) dengan menggunakan obat paling efektif dilakukan dalam 7 hari setelah terjadinya FA. Kardioversi farmakologis kurang efektif pada FA persisten. ${ }^{88}$

Terapi pengembalian irama ke sinus mempunyai kelebihan mengurangi risiko tromboemboli, memperbaiki hemodinamik dengan mengembalikan 'atrial kick' mencegah terjadinya respon ventrikel cepat yang dapat menginduksi kardiomiopati akibat takikardia, serta mencegah remodelling atrium yang dapat meningkatkan ukuran atrium dan menyebabkan kardiomiopati atrium. ${ }^{86}$

Kendali irama harus dipertimbangkan pada pasien gagal jantung akibat FA untuk memperbaiki keluhan, pasien muda yang simptomatik, atau FA sekunder akibat kelainan yang telah dikoreksi (iskemia, hipertiroid). ${ }^{41}$ Kondisi klinis yang dapat mempengaruhi tingginya rekurensi FA antara lain ukuran atrium kiri $>50 \mathrm{~mm}$, durasi $\mathrm{FA}>6$ bulan, gagal jantung dengan NYHA $>$ II, gangguan fungsi sistolik ventrikel kiri (Ejection Fraction (EF) $<40 \%$ ), disfungsi nodus sinoatrial,dan riwayat kardioversi sebelumnya (1-2 kali dalam 2 tahun sebelumnya). ${ }^{86}$

Beberapa obat antiaritmia untuk mengubah irama ke sinus juga memiliki efek samping dan seringkali membutuhkan perawatan di rumah sakit untuk inisiasinya. Keberhasilan kardioversi farmakologis juga tidak terlalu tinggi. Obat antiaritmia yang ada di Indonesia untuk kardioversi farmakologis adalah amiodaron dan propafenon. Namun amiodaron dalam penggunaan jangka panjang mempunyai efek toksik. $^{86}$

Propafenon tidak boleh diberikan pada pasien dengan penyakit jantung koroner atau gagaI jantung sistolik. Efektivitas obat antiaritmia untuk mengembalikan irama ke sinus hanyalah untuk mengurangi namun tidak menghilangkan kekambuhan FA. Obat antiaritmia tidak jarang mempunyai efek pro-aritmia dan efek samping lainnya di luar jantung. ${ }^{41}$
Gambar 10 menunjukkan pilihan terapi antiaritmia sesuai dengan kondisi patologis yang mendasari.

\section{IV.3.4. Kardioversi elektrik (direct current cardioversion)}

Kardioversi elektrik adalah salah satu strategi kendali irama. Keberhảsilan tindakan ini pada FA persisten mencapai angka $80-96 \%,{ }^{89}$ dan sebanyak $23 \%$ pasien tetap sinus dalam waktu setahun dan $16 \%$ dalam waktu dua tahun. ${ }^{90}$ Amiodaron adalah antiaritmia yang paling kuat mencegah terjadinya rekurensi FA setelah keberhasilan kardioversi. ${ }^{91}$ Kebanyakan rekurensi FA terjadi dalam 3 bulan pascakardioversi. ${ }^{92}$

Beberapa prediktor terjadinya kegagalan kardioversi atau rekurensi FA adalah berat badan,durasi FA yang lebih lama (>1-2 tahun), gagaI jantung dengan penurunan fraksi ejeksi, peningkatan dimensi atrium kiri, penyakit jantung rematik, dan tidak adanya pengobatan dengan antiaritmia. ${ }^{93}$

Ekokardiografi transtorakal harus dilakukan untuk identifikasi adanya trombus di ruang-ruang jantung. Bila trombus tidak terlihat dengan pemeriksaan

Tabel 7. Obat untuk kendali laju. ${ }^{41}$

\begin{tabular}{|c|c|c|c|}
\hline Kesehatan & Primer & Sekunder & Tersier \\
\hline \multicolumn{4}{|l|}{ Obat } \\
\hline $\begin{array}{l}\text { Penyekat Beta } \\
\text { - Metoprolol } \\
2 \times 50-100 \text { mg po }\end{array}$ & $\checkmark$ & $\checkmark$ & $\checkmark$ \\
\hline $\begin{array}{l}2,5-5 \mathrm{mg} \text { bolus intravena dalam } \\
2 \text { menit sampai } 3 \times \text { xdosis }\end{array}$ & - & $\checkmark$ & $\checkmark$ \\
\hline $\begin{array}{l}\text { - Bisoprolol } \\
1 \times 5-10 \mathrm{mg} \text { po }\end{array}$ & $r$ & $\checkmark$ & $\checkmark$ \\
\hline $\begin{array}{l}\text { - Atenolol } \\
1 \times 25-100 \mathrm{mg} p \mathrm{po}\end{array}$ & $r$ & 1 & 8 \\
\hline $\begin{array}{l}\text { - Propanolol } \\
3 \times 10-40 \mathrm{mg} \text { po }\end{array}$ & $\checkmark$ & 8 & $\checkmark$ \\
\hline $0,15 \mathrm{mg} / \mathrm{kgBB}$ dalam 1 menit & $r$ & $r$ & $\checkmark$ \\
\hline $\begin{array}{l}- \text { Carvediliol } \\
\text { 2×3,125-25 mg po }\end{array}$ & $\checkmark$ & $\checkmark$ & $\checkmark$ \\
\hline $\begin{array}{l}\text { Antagonis kanal kalsium non- } \\
\text { dihidropiridin } \\
\text { - Verapamil } \\
\text { Za40 sampai } 1 \times 240 \mathrm{mg} \text { po (lepas } \\
\text { lambat) }\end{array}$ & $\checkmark$ & $\checkmark$ & $\checkmark$ \\
\hline $\begin{array}{l}0,0375-0,15 \mathrm{mg} / \mathrm{kg} \mathrm{BB} \text { intravena } \\
\text { dalam } 2 \text { menit }\end{array}$ & - & $\checkmark$ & $\checkmark$ \\
\hline $\begin{array}{l}\text { - Diltiazem } \\
3 \times 30 \text { sampai } 1 \times 200 \mathrm{mg} \text { po (lepas } \\
\text { lambat) }\end{array}$ & $r$ & $r$ & $\checkmark$ \\
\hline Lainnya & & & \\
\hline $1 \times 0,125-0,5 \mathrm{mg}$ po & $\checkmark$ & $\checkmark$ & $\checkmark$ \\
\hline $0.5-1 \mathrm{mg} \mathrm{iv}$ & - & $\checkmark$ & $\checkmark$ \\
\hline $\begin{array}{l}\text { - Amiodaron } \\
1 \times 100-200 \mathrm{mg} \text { po }\end{array}$ & - & $\checkmark$ & $\checkmark$ \\
\hline $\begin{array}{l}5 \mathrm{mg} / \mathrm{kgBB} \text { dalam } 1 \text { jam dan } 50 \\
\text { mg/jam untuk rumatan }\end{array}$ & $\checkmark$ & $r$ & $\checkmark$ \\
\hline
\end{tabular}




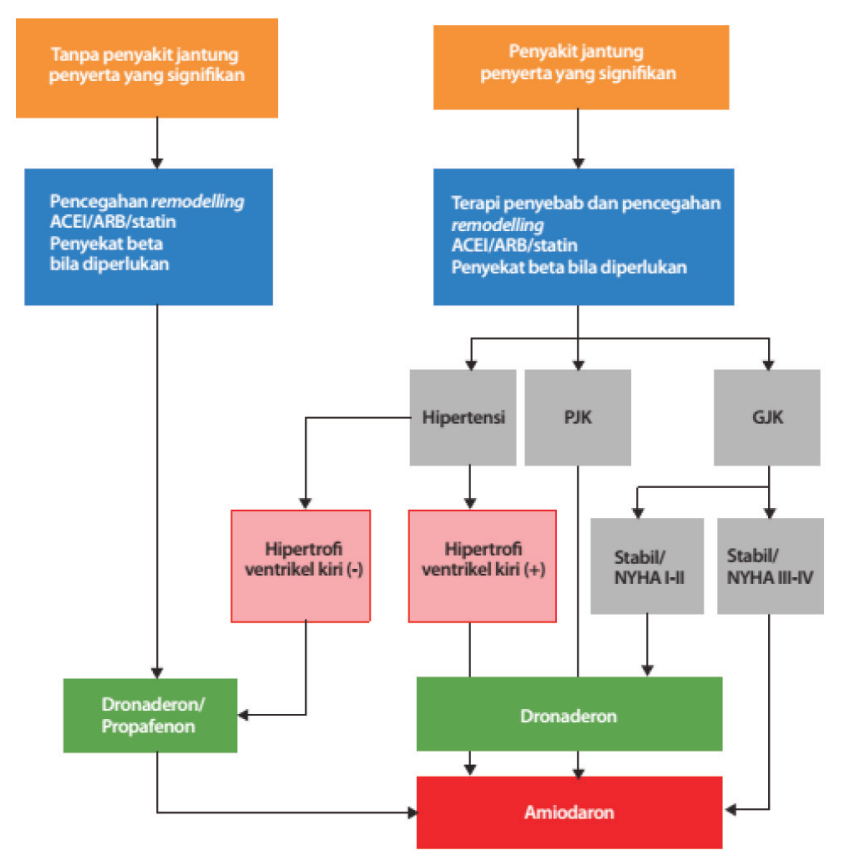

Gambar 10. Pilihan obat antiaritmia untuk kardioversi farmakologis. ACEI: Angiotensin Converting Enzyme Inhibitor, ARB: Angiotensin II Receptor Blocker, PJK: Penyakit Jantung Koroner, GJK: GagaI Jantung Kongestif (dimodifikasi dari referensi 2).

ekokardiografi transtorakal, maka ekokardiografi transesofagus harus dikerjakan apabila FA diperkirakan berlangsung $>48$ jam sebelum dilakukan tindakan kardioversi. ${ }^{41}$ Apabila tidak memungkinkan dilakukan ekokardiografi transesofagus, dapat diberikan terapi antikoagulan (AVK atau dabigatran) selama 3 minggu sebelumnya. ${ }^{94}$ Antikoagulan dilanjutkan sampai dengan 4 minggu pascakardioversi (target INR 2-3 apabila menggunakan AVK). ${ }^{92}$

Kardioversi elektrik dengan arus bifasik lebih dipilih dibandingkan arus monofasik karena membutuhkan energi yang lebih rendah dan keberhasilan lebih tinggi. Posisi anteroposterior mempunyai keberhasilan lebih tinggi dibanding posisi anterolateral. Komplikasi yang dapat terjadi adalah tromboemboli (1-2\%), aritmia pascakardioversi,dan risikoanestesi umum. Pemberian obat antiaritmia sebelum kardioversi, misalnya obat amiodaron, meningkatkan keberhasilan konversi irama FA ke irama sinus. ${ }^{41}$

\section{IV.3.5. Ablasi atrium kiri}

Keterbatasan terapi farmakologi dan kardioversi elektrik telah memunculkan jenis terapi yang lain seperti ablasi frekuensi-radio (AFR).8 Strategi ablasi merupakan salah cara untuk menyembuhkan FA pada beberapa populasi pasien. ${ }^{41}$ Evaluasi jangka panjang pada pasien ini menunjukkan irama sinus bertahan lebih lama dibandingkan pemakaian obat antiaritmia. Ablasi frekuensi-radio mempunyai keberhasilan $85 \%$ dalam 1 tahun pertama dan $52 \%$ dalam 5 tahun. ${ }^{8,41,95}$ Secara umum, AFR direkomendasikan pada pasien FA yang masih simtomatik meskipun telah dilakukan terapi medikamentosa optimal atau pasien memilih strategi kendali irama karena menolak mengonsumsi obat antiaritmia seumur hidup. ${ }^{84}$

Ostium VP yang terletak di atrium kiri merupakan sumber fokus ektopik yang mempunyai peranan penting dalam inisiasi dan mekanisme terjadinya FA. ${ }^{96}$ Ablasi frekuensi-radio pada fokus ektopik tersebut dapat mengeliminasi episode FA. Strategi AFR yang direkomendasikan adalah isolasi elektrik pada antrum VP dan AFR fokus ektopik. ${ }^{97}$

Beberapa efek samping seperti tromboemboli, stenosis VP, fistula atrioesofageal, tamponade, dan cedera saraf frenicus dapat terjadi pada pasien yang dilakukan AFR,sehingga tindakan ini harus dilakukan di pusat yang berpengalaman (komplikasi 2-3\%). ${ }^{41}$ Ablasi frekuensi-radio direkomendasikan pada pasien dengan FA simtomatik yang refrakter atau intoleran dengan 1 obat antiaritmia golongan 3 (amiodaron). ${ }^{80}$

Gambar 12 menunjukkan kapan dilakukan pemilihan tindakan AFR pada pasien FA. ${ }^{41}$

\section{IV.3.6. Ablasi dan modifikasi nodus atrioventikular (NAV)}

Ablasi NAV dilanjutkan dengan pemasangan pacu jantung permanen merupakan terapi yang efektif untuk mengontrol respon ventrikel pada pasien FA. Ablasi NAV adalah prosedur yang ireversibel sehingga hanya dilakukan pada pasien dimana kombinasi terapi gagal mengontrol denyut atau strategi kendali irama dengan obat atau ablasi atrium kiri tidak berhasil dilakukan. ${ }^{41,84}$

\section{IV.3.7. Terapi tambahan (upstream therapy)}

Terapi penunjang pada FA mencegah atau menghambat remodelling miokard akibat hipertensi, gagal jantung, atau inflamasi. Beberapa terapi yang termasuk dalam golongan ini adalah penghambat enzim konversi angiotensin (EKA), penyekat reseptor angiotensin, 


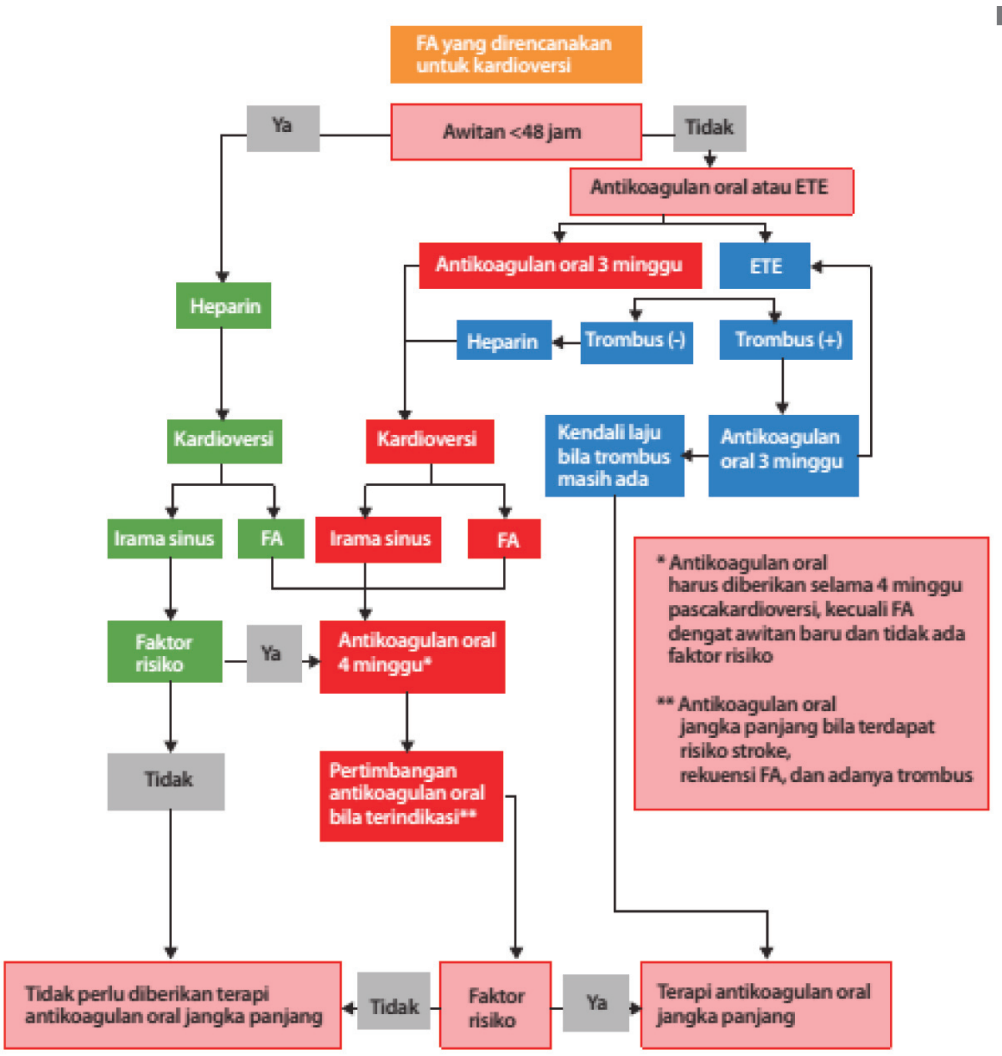

Gambar 11. Kardioversi pada pasien dengan FA. FA: fibrilasi atrium, ETE: ekokardiografi transesofageal (disadur dari referensi 2).

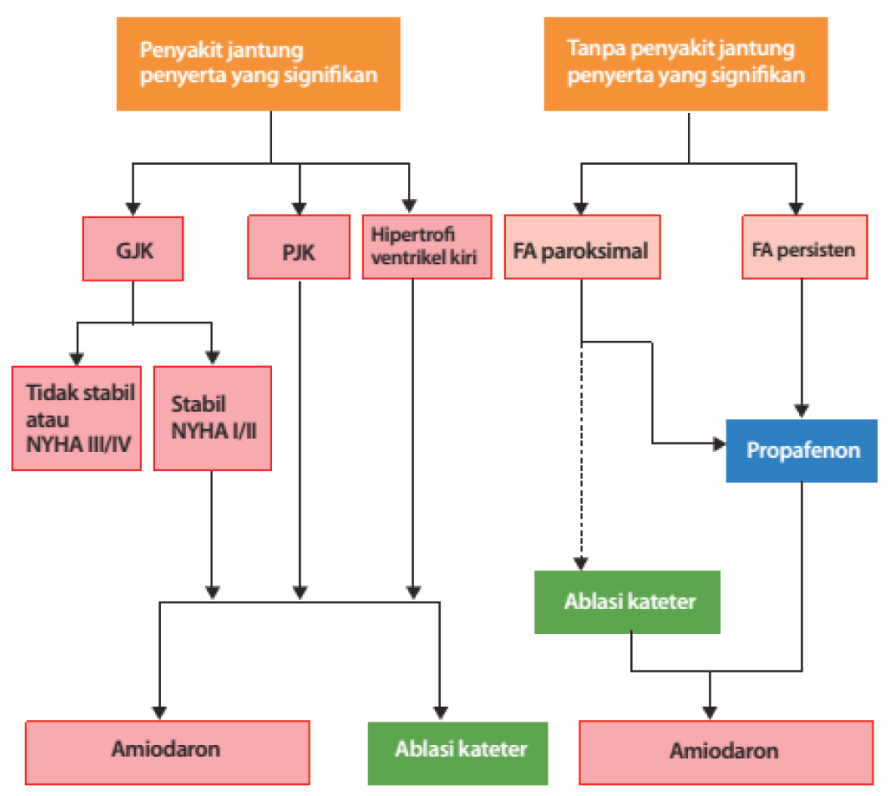

Gambar 12. Pemilihan tindakan AFR dan terapi obat antiaritmia. GJK: GagaI Jantung Kongestif, PJK: Penyakit Jantung Koroner, FA: Fibrilasi Atrium, NYHA: New York Heart Assosiation (dimodifikasi dari referensi 2). 
antagonis aldosteron, statin, dan omega 3. Penghambat EKA dan penyekat reseptor angiotensin menghambat efek aritmogenik angiotensin II, termasuk mencegah fibrosis atrium dan hipertrofi, stress oksidatif,serta inflamasi. Penggunaannya sebagai pencegahan primer terutama pada pasien dengan hipertensi, gagal jantung, dan adanya faktor risiko jantung koroner lainnya. Penghambat EKA dan penyekat reseptor angiotensin sebaiknya digunakan pada pasien dengan FA yang baru saja terjadi pada pasien gagal jantung dengan penurunan fraksi ejeksi dan hipertensi dengan hipertrofi ventrikel kiri. Pasien dengan hiperaldosteron primer mempunyai risiko 12 kali lipat mengalami FA. Antagonis aldosteron pada studi binatang dikatakan mampu menurunkan jumlah fibrosis atrium dan risiko terjadinya FA. Studi yang lebih besar pada manusia masih berjalan. Pemberian statin pada FA direkomendasikan pada pasien yang mengalami FA pascabedah pintas arteri koroner (BPAK) atau pasien gagal jantung dengan FA baru. Efek statin terutama terhadap proses aterosklerosis, anti inflamasi, dan antioksidan. ${ }^{41}$

\section{FIBRILASI ATRIUM PADA POPULASI KHUSUS}

\section{V.I. Pasien dengan gagal jantung}

Pada dasarnya tata laksana FA pada pasien dengan gagal jantung tidak berbeda dengan tata laksana FA pada subset lainnya. Tetapi obat antagonis kanal kalsium yang memiliki sifat inotropik negatif sebaiknya dihindari. Untuk kendali laju jantung pada FA sebaiknya menggunakan obat penyekat beta dan bila perlu dapat ditambahkan digitalis. Amiodaron adalah satu-satunya obat kendali irama yang dapat digunakan untuk pengobatan jangka panjang pada pasien dengan gagal jantung kelas fungsional lll dan IV. Pada kondisi gagal jantung akut, pilihan terapinya adalah kendali laju dengan pemberian digitalisasi cepat berupa digoksin 0,25-0,5 $\mathrm{mg}$ intravena (0,01-0,03 $\mathrm{mg} / \mathrm{kgBB} /$ hari). Pemberian dengan bolus selama 2 menit yang diencerkan dalam 10 cc larutan isotonis. Bila laju jantung belum terkontrol, bolus digoksin dapat diulang 4 jam setelah pemberian pertama dengan dosis maksimal $1,5 \mathrm{mg}$ per 24 jam.

\section{V.2. Atlet}

Olahraga yang berlebihan seperti yang dilakukan
Tabel 8. Rekomendasi pengobatan FA pada gagaI jantung

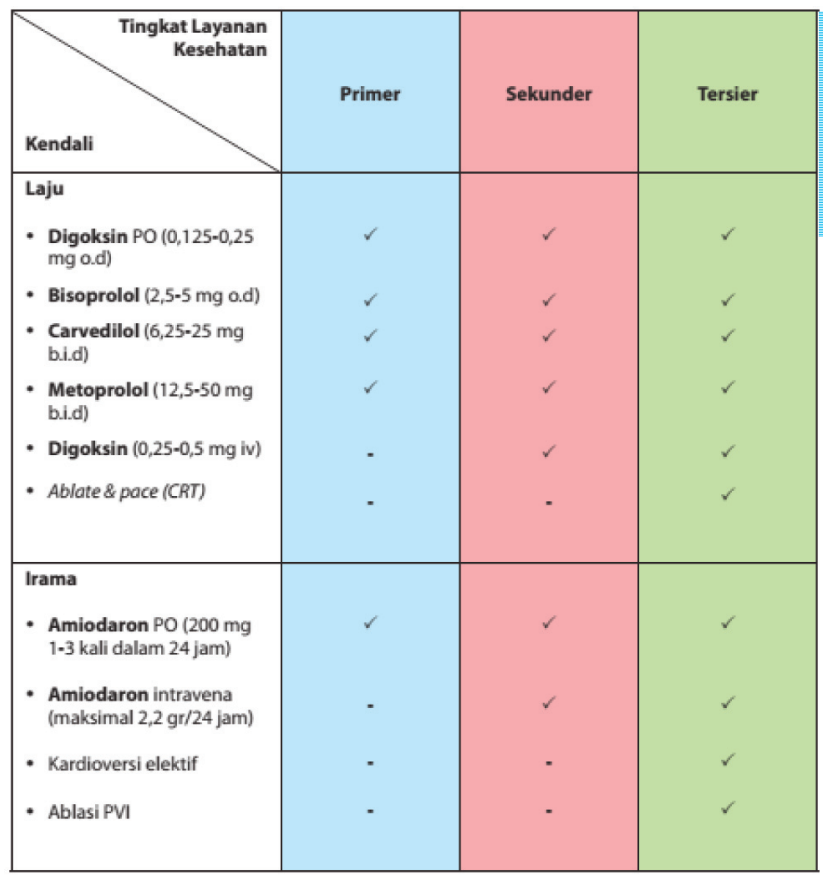

CRT: Cardiac Resynchronization Therapy; PVI: Pulmonary Vein Isolation

atlet dapat menjadi risiko tersendiri untuk terjadinya FA. ${ }^{98,99}$ Kesulitan pengendalian laju jantung pada FA dapat terjadi pada olahragawan karena tonus parasimpatis yang dominan pada populasi ini. Penyekat beta tidak dianjurkan dan sering tidak dapat ditoleransi dengan baik oleh atlet. Kepak atrium yang dapat timbul spontan atau setelah pemberian propafenon atau flekainid dapat membuat keadaan hemodinamik yang tidak stabil sehingga perlu hatihati dalam pemberiannya. ${ }^{100}$ Pemberian antagonis kanal kalsium non-dihidropiridin dan amiodaron lebih direkomendasikan pada populasi ini.

\section{V.3. Valvular}

Kelainan katup sering menimbulkan FA. Fibrilasi atrium paroksismal maupun permanen merupakan indikasi untuk dilakukan intervensi dini pada kelainan katup. ${ }^{101}$ Tata laksana FA pada kelainan katup umumnya hanya dapat dilakukan kendali laju, karena kendali irama sering sulit dilakukan terutama bila ukuran atrium kiri dari ekokardiografi $>45 \mathrm{~mm} .{ }^{102}$

Upaya kendali irama pada pasien stenosis mitral dapat dilakukan dengan kardioversi elektrik 
setelah kelainan katup dikoreksi dengan Baloon Mitral Valvuloplasty (BMV) ataupun operasi. Risiko terjadinya tromboemboli meningkat sehingga indikasi untuk terapi antikoagulasi oral sebaiknya dimulai dini. Kelainan katup dengan FA merupakan indikasi untuk pemberian antikoagulan oral jenis AVK (warfarin,Coumadin).

\section{V.4. Sindrom koroner akut (SKA)}

Fibrilasi atrium dapat terjadi pada $2-21 \%$ pasien dengan SKA. ${ }^{103}$ Dengan meningkatnya intervensi koroner perkutan dan prevensi sekunder, insiden FA dapat diturunkan. Pasien tua atau dengan gagal jantung mempunyai risiko lebih tinggi untuk terjadinya FA. Sindrom koroner akut dengan FA mempunyai risiko mortalitas dan stroke yang lebih tinggi. Kendali laju pada SKA tidak disarankan untuk menggunakan digoksin, karena dapat meningkatkan konsumsi oksigen miokard.

Pemberian AKB pada pasien dengan penyakit arteri koroner yang mendapat dual antiplatelet tidak menambah angka primary safety endpoint pada berbagai studi AKB. ${ }^{59,63}$

\section{V.5. Diabetes Melitus}

Diabetes dan FA sering dijumpai bersamaan. Ini dikarenakan keduanya berkaitan dengan penyakit arteri koroner, hipertensi, dan disfungsi ventrikel kiri, dan mungkin sebagai akibat dari disfungsi otonom dan kanalopati ion. Berbagaistudi pada populasimenunjukkan adanya diabetes pada $13 \%$ pasien dengan FA. ${ }^{26}$ Diabetes merupakan faktor risiko independen (RR 1,4-1,8) atas kejadian FA. Adanya diabetes dapat mengakibatkan prognosis buruk pada FA dengan meningkatkan angka kematian maupun kejadian kardiovaskular. Pendekatan komprehensif sangat diperlukan untuk manajemen risiko, termasuk mengontrol tekanan darah, terapi statin, dll. Pentingnya diabetes telah diakui di masingmasing skema stratifikasi risiko utama stroke dan terapi antikoagulan dianjurkan pada pasien dengan diabetes.

\section{V.6. Populasi lanjut usia (lansia)}

Prevalensi FA pada usia 80 tahun berkisar 10\% dan $18 \%$ pada mereka yang berusia 85 tahun.

Penelitian yang bertujuan untuk penyaringan FA
Tabel 9. Rekomendasi pengobatan FA pada kelainan katup

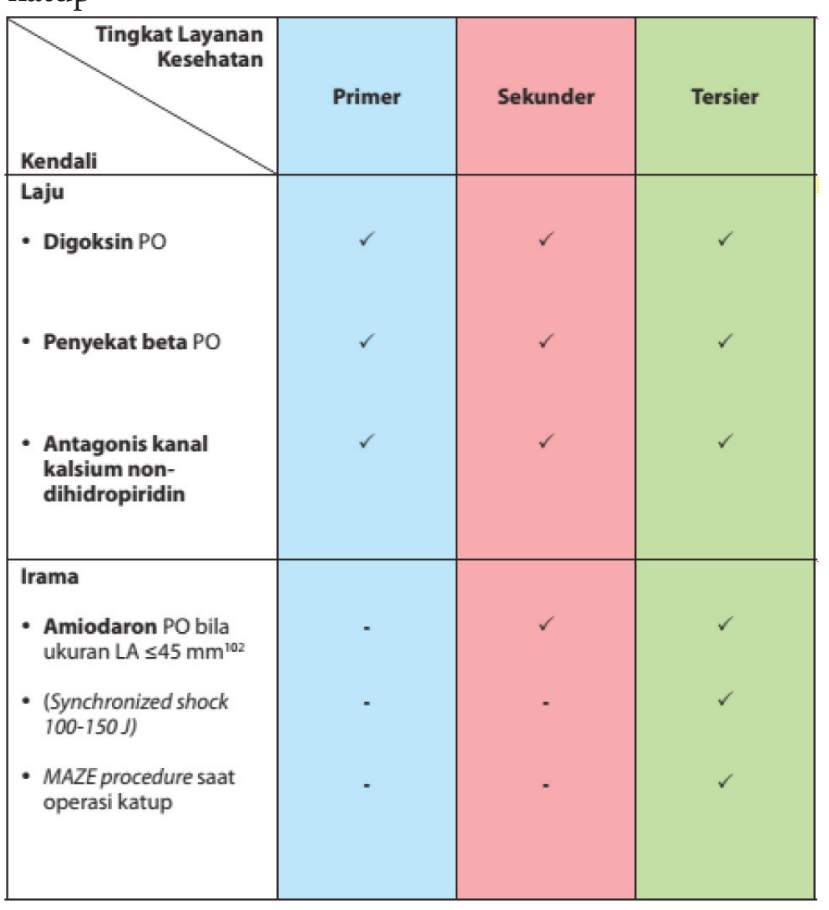

pada lansia di layanan kesehatan primer ( $S A F E$ study) ${ }^{105}$ menemukan bahwa penapisan umum oleh dokter umum, diikuti oleh EKG ketika denyut jantung tidak teratur, sama efektifnya dengan penapisan sistematis dengan EKG. Semua pasien berusia $>75$

Tabel 10. Rekomendasi penggunaan antikoagulan pada pasien yang menggunakan dua antiplatelet. ${ }^{104}$

\begin{tabular}{|c|c|c|}
\hline Risiko perdarahan & Jenis stent & Regimen terapi \\
\hline $\begin{array}{l}\text { Rendah atau sedang } \\
\text { (Contoh: } \\
\text { skor HAS-BLED 0-2) }\end{array}$ & $\begin{array}{l}\text { Stent bare metal/ } \\
\text { salut obat }\end{array}$ & $\begin{array}{l}6 \text { bulan pertama: } \\
\text { Kombinasi } 3 \text { obat: antikoagulan aral (INR 2,0- } \\
2,5)+ \text { aspirin } \leq 100 \mathrm{mg} / \text { hari }+ \text { clopidogrel } 75 \\
\text { mg/hari } \\
6-12 \text { bulan: } \\
\text { Kombinasi } 2 \text { obat : antikoagulan oral (INR } \\
2,0-2,5)+ \text { clopidogrel } 75 \text { mg/hari (atou aspirin } \\
100 \mathrm{mg} / \text { hari) } \\
\text { Seumur hidup : } \\
\text { Hanya antikoagulan oral (INR 2-3) }\end{array}$ \\
\hline $\begin{array}{l}\text { Tinggi } \\
\text { (Contoh: } \\
\text { skor HAS-BLED } \geq 3 \text { ) }\end{array}$ & Stent bare metal & 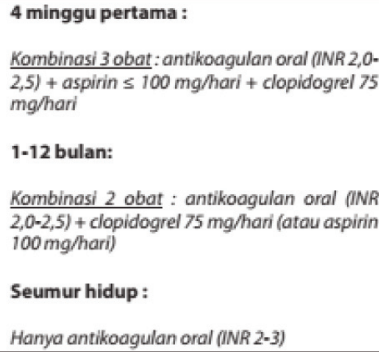 \\
\hline
\end{tabular}




\section{Manajemen antitrombotik pada FA/KA dengan PJK}

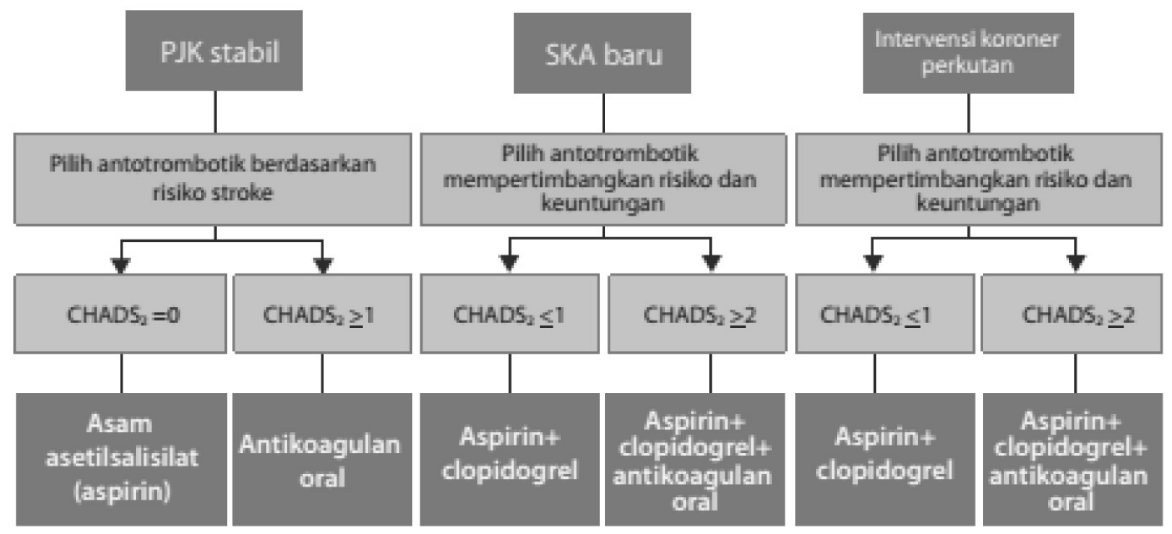

Gambar 13. Ringkasan rekomendasi untuk manajemen antitrombotik pada keadaan penyakit jantung koroner. SKA: sindrom koroner akut, FA: fibrilasi atrium, KA: kepak atrium, PJK:penyakit jantung koroner, $\mathrm{CHADS}_{2}$ : Congestive Heart Failure, Hypertension, Age >75, Diabetes Mellitus, and Prior Stroke or Transient Ischemic Attack (disadur dari referensi 72).

tahun dengan FA memiliki risiko tromboemboli > 4\% pertahun, melebihi batas indikasi dimana AVK harus diberikan kecuali terdapat risiko perdarahan yang sangat tinggi. Pada komponen individual dari skor $\mathrm{CHA}_{2} \mathrm{DS}_{2}$ VASc $\geq 75$ tahun mengakibatkan prognosis yang lebih buruk untuk stroke dan kematian, lebih besar jika dibandingkan dengan hipertensi, diabetes, atau gagal jantung.

Secara umum, pengobatan AVK dan AKB dapat ditoleransi dengan baik pada populasi lansia. Studi acak terkontrol dengan AVK pada FA menunjukkan adanya penurunan kejadian stroke iskemikdan kejadian kardiovaskular, dengan hanya sedikit peningkatan kejadian perdarahan berat. Secara keseluruhan AVK mempunyai manfaat lebih besar pada orang tua, bila dibandingkan dengan aspirin. Sebaliknya, efek menguntungkan dari terapi antiplatelet pada stroke iskemik tampaknya menurun sejalan dengan usia dan tidak mempunyai efek protektif lagi pada usia $>77$ tahun.

Kardioversi elektrik jarang dilakukan pada lansia karena irama sinus seringkali sulit untuk dipertahankan. ${ }^{106}$

Untuk lansia dengan tingkat aktivitas yang rendah, digoksin dapat menjadi pilihan untuk kendali laju karena digoksin lebih efektif pada tonus simpatis yang rendah. Penggunaan penyekat beta dan antagonis kalsium non-dihidropiridin juga efektif untuk kendali laju. Penyekat beta harus digunakan dengan hati-hati untuk pasien lansia dengan PPOK.

Pasien lansia dengan FA memiliki ciri-ciri berbeda dari pasien muda, yaitu rapuh, memiliki banyak komorbiditas termasuk kardiovaskular maupun penyakit non-jantung, mempunyai angka insiden dan prevalensi FA yang tinggi, risiko tromboemboli dan perdarahan yang tinggi, FA bersifat persisten atau permanen, seringkali dijumpai gejala dan keluhan yang tidak khas, respon ventrikel pada FA kurang sensitif terhadap efek simpatis (penuaan sistem konduksi), lebih sensitif terhadap efek obat pro-aritmia akibat menurunnya fungsi ginjal dan hati, serta lebih sulit terdeteksi bila dibandingkan dengan pasien yang lebih muda.

Pemberian AKB dabigatran pada lansia memakai dosis $110 \mathrm{mg}$ b.i.d untuk menghindari peningkatan kejadian perdarahan. Sedangkan pada rivaroxaban dan apixaban tidak memerlukan penyesuaian dosis. ${ }^{44,101,108}$

\section{V.7. Kehamilan}

Fibrilasi atrium jarang terjadi selama kehamilan pada wanita tanpa riwayat FA sebelumnya dan tanpa adanya penyakit jantung penyerta. Pada pasien yang sebelumnya sudah didiagnosis FA, 52\% mengalami rekurensi selama kehamilan. Selain itu, komplikasi 
pada bayi lebih tinggi pada wanita yang mengalami FA selama kehamilan. Fibrilasi atrium selama kehamilan ditoleransi dengan baik pada kebanyakan pasien tanpa penyakit katup atau penyakit jantung bawaan.

\section{Obat kendali laju}

Penyekat beta dapat melewati sawar plasenta dan berkaitan dengan berbagai efek samping termasuk gangguan pertumbuhan intrauterus, depresi pernapasan neonatal, bradikardia, dan hipoglikemia pada janin, terutama jika pengobatan dimulai pada awal kehamilan (misalnya 12-24 minggu). Pada kehamilan dengan komplikasi hipertensi yang diobati dengan propranolol tidak ditemukan kejadian anomali kongenital, namun dilaporkan adanya hambatan pertumbuhan jan in. Atenolol yang diberikan pada trimester pertama berkaitan dengan retardasi pertumbuhan janin. Hal ini tidak ditemukan pada pemberian trimester 2-3. Sebuah analisis-meta untuk menilai pemberian penyekat beta pada pasien hipertensi dalam kehamilan menemukan adanya peningkatan kejadian kecil untuk masa kehamilan. Digoksin dapat melewati plasenta secara bebas dan intoksikasi digitalis pada ibu berkaitan dengan kematian janin. Data yang ada untuk penggunaan verapamil dan diltiazem terbatas tetapi penggunaan oral untuk kendali laju pada umumnya bersifat aman.

\section{Obat untuk konversi FA}

Amiodaron terbukti mempunyai efek negatif pada janin bila digunakan pada wanita hamil dan hanya boleh digunakan dalam situasi yang mendesak. Sedapat mungkin, semua obat dihindari selama periode organogenesis pada trimester pertama kehamilan.

\section{Kardioversi elektrik}

Beberapa laporan kasus telah menunjukkan kardioversi yang sukses pada ibu dengan FA tidak membahayakan janin. Tidak ada perbedaan energi kardioversi elektrik yang digunakan pada wanita hamil dibandingkan wanita lain. ${ }^{109}$

\section{Antikoagulasi}

Antagonis vitamin $\mathrm{K}$ dapat bersifat teratogenik dan dalam banyak kasus harus diganti dengan
Unfractionated Heparin (UFH) atau Low Molecular Weight Heparin (LMWH) pada trimester pertama. Pemberian warfarin menyebabkan malformasi janin pada $6,4 \%$ kasus, sementara bila pengobatan diubah menjadi heparin antara minggu 6-12 tidak didapatkan adanya kejadian bermakna. ${ }^{110}$ Warfarin dapat melintasi sawar darah-plasenta dan janin dapat mengalami kelebihan dosis bahkan ketika ibu berada dalam kisaran INR terapeutik.

Low Molecular Weight Heparin tidak dapat melewati sawar darah-plasenta dan telah banyak digunakan untuk pengobatan dan pencegahan tromboemboli vena selama kehamilan tanpa adanya efek negatif pada janin. Pada trimester ketiga, pemeriksaan laboratorium yang lebih sering untuk penyesuaian dosis antikoagulasi yang adekuat sangat dianjurkan (misalnya setiap 10-14 hari). Pasien hamil dengan FA dan katup prostese mekanik yang memutuskan untuk menghentikan penggunaan AVK antara minggu ke-6 dan 12 kehamilan harus mendapat UFH intravena secara berkelanjutan dengan penyesuaian dosis UFH atau LMWH subkutan. Antagonis vitamin $\mathrm{K}$ dapat dilanjutkan kembali pada trimester kedua dimana hanya terdapat sedikit peningkatan risiko teratogenik.

\section{V.8. Fibrilasi atrium pascabedah jantung}

Fibrilasi atrium merupakan komplikasi yang paling sering terjadi setelah operasi jantung: pasca-BPAK sebesar $30 \%$, operasi katup $40 \%$, operasi kombinasi BPAK dan katup 50\%. ${ }^{111}$ Puncak kejadian terutama antara hari ke 2-4 pascabedah.

Untuk pencegahan FA pascabedah dapat diberikan penyekat beta. Paling efektif bila pemberian penyekat beta sebelum dan setelah bedah jantung dibandingkan dengan hanya sebelum atau setelah bedah saja. ${ }^{112,113}$ Terapi diberikan minimal 1 minggu sebelum bedah. Mayoritas FA pascabedah dengan hemodinamik stabil akan kembali ke irama sinus secara spontan dalam waktu 24 jam. lata laksana awal meliputi koreksi faktor predisposisi (seperti manajemen nyeri, optimalisasi hemodinamik, weaning inotropik intravena, koreksi elektrolit, anemia, hipoksia dan kelainan metabolik).

Fibrilasi atrium simtomatis dan laju yang sulit dikendalikan dengan medikamentosa, dapat dilakukan kardioversi. Tingkat keberhasilan kardioversi elektrik sebesar 95\% dalam menghentikan FA meskipun demikian terapi farmakologis lebih 
Tabel 11. Rekomendasi pengobatan FA pada kehamilan

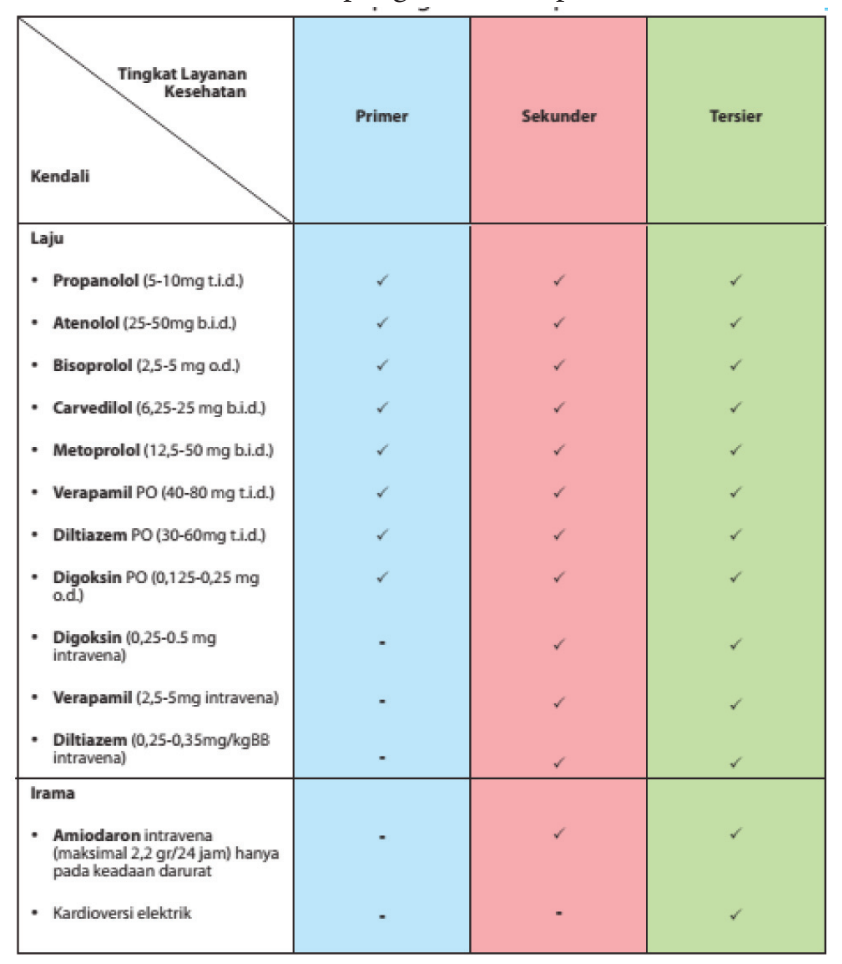

sering digunakan.

Antikoagulan (heparin) harus diberikan pada FA yang berlangsung lebih dari 48 jam pad a pasien pascabedah jantung serta harus diberikan sebelum kardioversi.

\section{V.9. Hipertiroid}

Fibrilasi atrium terjadi pada $10-25 \%$ pasien dengan hipertiroid terutama pada laki-laki dan, orang tua. ${ }^{114,115}$ Pengobatan terutama ditujukan untuk mengembalikan ke status eutiroid, sehingga memudahkan konversi spontan ke irama sinus. Jika strategi kendali irama yang dipilih, untuk mengurangi risiko kekambuhan kembali fungsi tiroid harus dinormalkan sebelum kardioversi. Obat antiaritmia dan kardioversi elektrik umumnya hanya berhasil sesaat jika masih dalam status tirotoksikosis.

Penyekat beta dapat diberikan untuk kendali laju dan pemberian penyekat beta intravena dosis tinggi berguna pada krisis tiroid. Pilihan terapi yang lain yang dapat diberikan adalah antagonis kalsium non-dihidropiridin (diltiazem dan verapamil).

Meskipun bukti masih kurang, bila ada faktor risiko untuk terjadinya stroke,pemberian terapi antioagulan oral dianjurkan untuk mencegah emboli sistemik.

Hipertiroidisme dapat terjadi setelah pemberian amiodaron. Ada dua jenis hipertiroidisme yang diinduksi oleh amiodaron: tipe I, yaitu peningkatan produksi T4 dan T3 yang diinduksi iodin dan tipe II, yaitu tiroiditis destruktif dengan kelebihan pelepasan T4 dan T3 yang menyebabkan penurunan fungsi tiroid. Pemberian amiodaron harus dihentikan pada hipertiriodisme. Sebagai alternatif dapat diberikan dronedaron, yaitu derivat amiodaron yang tidak mengandung iodin sehingga mengurangi insiden tirotoksikosis. ${ }^{116}$

\section{V.10. Sindrom Wolff-Parkinson-White}

Pada pasien dengan jaras tambahan dan FA berisiko terhadap diteruskannya konduksi dari atrium ke ventrikel melalui jaras tambahan sehingga menghasilkan laju ventrikel yang sangat cepat dan berpotensi menimbulkan kematian jantung mendadak akibat degenerasi ke fibrilasi ventrikel.

\section{Stratifikasi risiko kematian jantung mendadak}

Insiden kematian jantung mendadak pada sindrom WPW berkisar antara 0,15-0,39\% selama pengamatan 3 sampai 22 tahun.117,118 Pasien yang berisiko tinggi adalah yang memiliki interval RR yang pendek $<250$ mdet selama FA spontan maupun terinduksi, riwayat takikardia simtomatik, adanya jaras tambahan yang multipel atau anomali Ebstein. ${ }^{19,120}$ Takikardia preeksitasi yang terjadi pada pasien dengan takikardi atrium atau kepak atrium, juga dapat menyebabkan laju ventrikel yang cepat dan dapat berdegenerasi menjadi takikardia ventrikel.

Efektivitas ablasi kateter pada jaras tambahan mencapai 95\% sehingga merupakan pilihan terapi untuk pasien dengan preeksitasi dan FA. ${ }^{121}$ Pasien yang selamat dari kematian jantung mendadak dengan adanya jaras tambahan merupakan kandidat untuk dilakukan ablasi segera. Ablasi yang berhasil tidak perlu diikuti dengan pemasangan Implantable Cardioverter Defibrillator (ICD). Pasien dengan preeksitasi dan risiko tinggi FA atau pasien dengan profesi risiko tinggi seperti pengemudi mobil, pilot, atau atlet juga dipertimbangkan untuk ablasi. Indikasi ablasi jaras tambahan pada pasien yang asimtomatik masih kontroversial. Umumnya pasien preeksitasi yang asimtomatik ini mempunyai prognosis yang baik. 
Jurnal Kardiologi Indonesia

\section{V.I I. Kardiomiopati Hipertrofik (KMH)}

Pasien KMH mempunyai risiko terkena FA lebih besar dibanding populasi umum. Prevalensi FA sekitar $15 \%$ dengan insiden $2 \%$ per tahun. ${ }^{8,122}$ Fibrilasi atrium merupakan penentu klinis terjadinya perburukan. Kardioversi elektrik dan medikamentosa diindikasikan pada kasus akut tanpa adanya trombus d i atrium pada KMH. Amiodaron merupakan obat yang paling efektif dalam menurunkan kejadian FA paroksismal dan mencegah rekurensi. Pada FA kronis, pemberian obat golongan penyekat beta dan verapamil biasanya efektif untuk kontrol laju. Pada pasien dengan gradien dinamik yang tinggi pada alur keluar ventrikel kiri, ablasi NAV dengan pacu jantung permanen dapat memperbaiki simtom. ${ }^{123}$

Terapi dengan obat antikoagulan oral harus diberikan pada pasien dengan $\mathrm{KMH}$ dan FA paroksismal, persisten atau permanen. Keberhasilan ablasi FA pada KMH sangat bervariasi. Sekitar $67 \%$ pasien dengan FA refrakter dan simtomatik, walaupun telah diberikan terapi medikamentosa termasuk amiodaron, akan mengalami perbaikan dan kembali ke irama sinus setelah ablasi kateter.

\section{V.I2. Penyakit Paru}

Takikardi atrium multifokal banyak ditemukan pada kasus PPOK dan sering disalahartikan. Fibrilasi atrium pada pasien penyakit paru kronik dapat menyebabkan eksaserbasi akut yang berhubungan dengan hipoksia. Terapi terhadap penyebab kelainan paru dan koreksi gangguan elektrolit harus menjadi perhatian utama karena sebagai FA.

Obat-obat yang dapat meredakan bronkospasme seperti teofilin dan agonis beta dapat mencetuskan FA sehingga kendali laju menjadi sulit. Golongan obat penyekat beta non-selektif, propafenon dan adenosin merupakan kontraindikasi pada pasien dengan bronkospasme. Penggunaan sotalol, antiaritmia golongan III yang juga merupakan penyekat beta harus diberikan dengan hati-hati pada bronkospasme. Pada keadaan ini antagonis kalsium merupakan pilihan yang lebih baik. Penyekat beta selektif (sebagai contoh bisoprolol) pada dosis kecil sering dapat ditoleransi dan cukup efektif. Pada kasus FA yang resisten, ablasi NAV dan pemasangan pacu jantung ventrikel mungkin dibutuhkan untuk kendali laju ventrikel.

\section{Daftar Pustaka}

1. Go AS, Hylek EM, Phillips KA, et al. Prevalence of diagnosed atrial fibrillation in adults: national implications for rhythm management and stroke prevention: the AnTicoagulation and Risk Factors in Atrial Fibrillation (ATRIA) Study. JAMA : the journal of the American Medical Association 2001;285:23705.

2. European Heart Rhythm A, European Association for CardioThoracic S, Camm AJ, et al. Guidelines for the management of atrial fibrillation: the Task Force for the Management of Atrial Fibrillation of the European Society of Cardiology (ESC). European heart journal 2010;31:2369-429.

3. Wolf PA, Benjamin EJ,Belanger AJ,Kannel WB,Levy D,D:A.gostino RB. Secular trends in the prevalence of atrial fibrillation:The Framingham Study.American heartjournal1996;131:790-5.

4. Setianto B,Malik MS,Supari SF. Studi aritmia pada survei dasar MONICA-Jakarta di Jakarta Selatan. Badan Penelitian dan Pengembangan Kesehatan Depkes Rl 1998.

5. Rl PDdiKK. Gambaran kesehatan usia lanjut di Indonesia. Buletin Jendela Data dan lnformasi Kesehatan 2013:.

6. Wyse DG, Waldo AL, DiMarco JP. et al. A comparison of rate control and rhythm control in patients with atrial fibrillation. The New England journal of medicine 2002;347:1825-33.

7. StewartS,Murphy NF, Walker A,McGuire A,McMurray JJ.Cost of an emerging epidemic: an economic analysis of atrial fibrillation in the UK. Heart 2004;90:286-92.

8. Camm AJ, Lip GY, De Caterina R, et al. 2012 focused update of the ESC Guidelines for the management of atrial fibrillation:an update ofthe 2010 ESC Guidelines forthe management of atrial fibrillation--developed with the special contribution of the European Heart Rhythm Association. Europace : European pacing, arrhythmias, and cardiac electrophysiology: journal of the working groups on cardiac pacing, arrhythmias, and cardiac cellular electrophysiology ofthe European Society of Cardiology 2012;14:1385 -413.

9. Issa ZF. Atrial Fibrillation. In: Miller JM, Zipes DP, eds. Clinical arrhythmology and electrophysiology: a companion to Braunwald's heart disease. 2nd ed: Saunders;2012.

10. BenoniM, Zimmermann M.Autonomic tone variations before the onset of paroxysmalatrial fibrillation.Circulation 2002;105:2753-9.

11. Po SS,Scherlag BJ,Yamanashi WS,et al. Experimental model for paroxysmal atrial fibrillation arising at the pulmonary veinatrial junctions. Heart rhythm: the official journal of the Heart Rhythm Society 2006;3:201-8.

12. Daoud EG,Bogun F,Goyal R,et al. Effect of atrial fibrillation on atrial refractoriness in humans. Circulation 1996;94:1600-6.

13. Fuster V, Ryden LE,Cannom DS,et al. 2011 ACCF/AHA/ HRS focused updates incorporated into the ACC/AHNESC 
2006 Guidelines for the management of patients with atrial fibrillation: a report of the American College of Cardiology Foundation/American Heart Association Task Force on Practice Guidelines developed in partnership with the European Society of Cardiology and in collaboration with the European Heart Rhythm Association and the Heart Rhythm Society.Journal of the American College of Cardiology 2011;57:e101-98.

14. Moe GK. Rheinboldt WC Abildskov JA.A Computer Model of Atrial Fibrillation. American heart journal1964;67:200-20.

15. Wijffels MC Kirchhof CJ,Dorland R,Allessie MA.Atrial fibrillation begets atrial fibrillation. A study in awake chronically instrumented goats. Circulation 1995;92:1954-68.

16. Fox CS, Parise H, D’Agostino RB, Sr., et al. Parental atrial fibrillation as a risk factor for atrial fibrillation in offspring. JAMA : the journal of the American Medical Association 2004;291:2851-5.

17. Kirchhof P, Bax J, Blomstrom-Lundquist $\mathrm{C}$ et al. Early and comprehensive management of atrial fibrillation: executive summary of the proceedings from the 2nd AFNET-EHRA consensus conference 'research perspectives in AF: European heart journal 2009;30:2969-llc.

18. Hodgson-Zingman DM, Karst ML. Zingman LV, et al. Atrial natriuretic peptide frameshift mutation in familial atrial fibrillation. The New England journalof medicine 2008;359:158-65.

19. Olson TM, Michels VV, Ballew JD, et al. Sodium channel mutations and susceptibility to heart failure and atrial fibrillation. JAMA: the journal of the American Medical Association 2005;293:447-54.

20. Chen $\mathrm{YH}, \mathrm{Xu}$ SJ, Bendahhou S, et al. KCNQ1 gain-of-function mutation in familial atrial fibrillation.Science 2003;299:2514.

21. Gudbjartsson DF, Holm H, Gretarsdottir S, et al. A sequence variant in ZFHX3 on 16q22 associates with atrial fibrillation and ischemic stroke.Nature genetics 2009;41:876-8.

22. Alpert JS,Petersen P, Godtfredsen J. Atrial fibrillation: natural history, complications, and management. Annual review of medicine 1988;39:41-52.

23. Packer DL. Bardy GH,Worley SJ, et al. Tachycardia-induced cardiomyopathy: a reversible form of left ventricular dysfunction. The American journal of cardiology 1986;57:563-70.

24. Watson T,Shantsila E,Lip GY. Mechanisms ofthrombogenesis in atrial fibrillation: Virchow's triad revisited. Lancet 2009;373:155-66.

25. BelletS. Clinical Disorders ofthe Heart Beat.3rd ed.Philadelphia: Lea \& Febiger; 1971.

26. European Heart Rhythm A, European Association for CardioThoracic S, Camm AJ, et al. Guidelines for the management of atrial fibrillation: the Task Force for the Management of Atrial Fibrilal tion of the European Society of Cardiology (ESC).Europace: European pacing, arrhythmias, and cardiac electrophysiology : journal of the working groups on cardia c pacing, arrhythmias, and cardiac cellular electrophysiology of the European Society of Cardiology 2010;12:1360-420.

27. Fuster V, Ryden LE,Cannom DS,et al. ACC/AHA/ESC 2006 Guidelines for the Management of Patients with Atrial Fibrillation: a report ofthe American College of Cardiology/American Heart Association Task Force on Practice Guidelines and the European Society of Cardiology Committee for Practice Guidelines (Writing Committee to Revise the 2001 Guidelines for the Management of Patients With Atrial Fibrillation): developed in collaboration with the European Heart Rhythm Association and the Heart Rhythm Society. Circulation 2006; 114:e257.354.

28. Levy S, Breithardt G, Campbell RW, et al. Atrial fibrillation: current knowledge and recommendations for management. Working Group on Arrhythmias of the European Society of Cardiology. European heart journal1998;19:1294.320.

29. Wann LS, Curtis AB, January CT. et al. 2011 ACCF/AHA/ HRS focused update on the management of patients with atrial fibrillation (Updating the 2006 Guideline): a report of the American College of Cardiology Foundation/American Heart Association Task Force on Practice Guidelines.Journal of the American College of Cardiology 2011;57:223.42.

30. Knight BP,Michaud GF, Strickberger SA, Morady F. Electrocardiographic differentiation of atrial flutter from atrial fibrillation by physicians.Journalofelectrocardiology 1999;32:315-9.

31. Defaye P, Dournaux F, Mouton E. Prevalence of supraventricular arrhythmias from the automated analysis of data stored in the DDD pacemakers of 617 patients: the AIDA study. The AIDA Multicenter Study Group. Automatic Interpretation for Diagnosis Assistance. Pacing and clinical electrophysiology: PACE 1998;21:250-5.

32. Atrial Fibrillation (A Fib) Awareness. 2013. at http://www. hrsonline.org/News/Atriai Fibrillation.AFib.Awareness\#axzz 2gHiiCTk0.)

33. Page RL Wilkinson WE, Clair WK. McCarthy EA, Pritchett EL. Asymptomatic arrhythmias in patients with symptomatic paroxysmal atrial fibrillation and paroxysmal supraventricular tachycardia.Circulation 1994;89:224-7.

34. Atrial Fibrillation Clinical Presentation. 2013. (Accessed Sep 27, 2013, at http://emedicine. medseape.com/article/151066clinica1.)

35. Cheng M, Hu Z, LuX,Huang J Gu D. Caffeine intake and atrial fibrillation incidence: Dose response Meta-analysis of prospective cohort studies.Canadian Journalof Cardiology 2014.

36. van den 8os EJ,Constantinescu AA,van Domburg RT. Akin S,Jordaens LJ, Kofflard MJ.Minor elevations in troponin I are associated with mortality and adverse cardiac events in patients with atrial fibrillation. European heartjournal2011;32:611-7.

37. Wozakowska-Kaplon B. Effect of sinus rhythm restoration on 


\section{Jurnal Kardiologi Indonesia}

plasma brain natriuretic peptide in patients with atrial fibrillation. The American journal of cardiology 2004;93:1555-8.

38. Kowey PR, Yannicelli D,Amsterdam E. Effectiveness of oral propafenone for the prevention of atrial fibrillation after coronary artery bypass grafting. The American journal of cardiology 2004;94:663 -5.

39. Singer DE,Albers GW,Dalen JE,et al. Antithrombotic therapy in atrial fibrillation: American College of Chest Physicians Evidence-Based Clinical Practice Guidelines (8th Edition). Chest 2008;133:546S.92S.

40. Wolf PA, Dawber TR,Thomas HE,Jr., Kannel WB.Epidemiologic assessment of chronic atrial fibrillation and risk of stroke: the Framingham study.Neurology 1978;28:973-7.

41. Camm AJ,Lip GY, De Caterina R, et al. 2012 focused update ofthe ESC Guidelines for the management of atrial fibrillation: an update of the 2010 ESC Guidelines for the management of atrial fibrillation.Developed with the special contribution ofthe European Heart Rhythm Association.European heart journal2012;33:2719-47.

42. Group SRiAFW. Independent predictors of stroke in patients with atrial fibrillation: a systematic review. Neurology 2007;69:546-54.

43. Hughes M,Lip GY,Guideline Development Group NCGfMoAFiP. Secondary Care NlfH,Clinical E. Stroke and thromboembolism in atrial fibrillation: a systematic review of stroke risk factors,risk stratification schema and cost effectiveness data. Thrombosis and haemostasis 2008;99:295-304.

44. Lip GY, Nieuwlaat R, Pisters R, Lane DA, Crijns HJ. Refining clinical risk stratification for predicting stroke and thromboembolism in atrial fibrillation using a novel risk factor-based approach: the euro heart survey on atrial fibrillation.Chest 2010;137:263-72.

45. Banerjee A, Taillandier S, Olesen JB, et al. Ejection fraction and outcomes in patients with atrial fibrillation and heart failure: the LoireValley AtrialFibrillation Project.European journal of heart failure 2012;14:295-301.

46. Friberg L Rosenqvist M,Lip GY.Evaluation of risk stratification schemes for ischaemic stroke and bleeding in 182678 patients with atrial fibrillation: the Swedish Atrial Fibrillation cohort study. European heart journal2012;33:1500-10.

47. Friberg L Benson L Rosenqvist M, Lip GY.Assessment of female sex as a risk factor in atrial fibrillation in Sweden: nationwide retrospective cohort study. Bmj 2012;344:e3522.

48. Olesen JB, Fauchier L Lane DA, Taillandier S, Lip GY. Risk factors for stroke and thromboembolism in relation to age among patients with atrial fibrillation: the Loire Valley Atrial Fibrillation Project.Chest 2012;141:147-53.

49. Boriani G,Botto GL Padeletti Let al. Improving stroke risk stratification using the CHADS2 and CHA2DS2 VASc risk scores in patients with paroxysmal atrial fibrillation by continuous arrhythmia burden monitoring. Stroke; journal of cerebral circulation 2011;42:1768-70.

50. Olesen JB,Torp-Pedersen C Hansen ML Lip GY. The value of the CHA2DS2-VASc score for refining stroke risk stratification in patients with atrial fibrillation with a CHADS2 score 0-1: a nationwide cohort study. Thrombosis and haemostasis 2012;107:1172-9.

51. Olesen JB,Lip GY,Hansen ML et al. Validation of risk stratification schemes for predicting stroke and thromboembolism in patients with atrial fibrillation: nationwide cohort study. Bmj 2011;342:dl24.

52. Chao TF,Lin YJ. Tsao HM, et al. CHADS(2) and CHA(2)DS(2)VASc scores in the prediction of clinical outcomes in patients with atrial fibrillation after catheter ablation. Journal of the American College of Cardiology 2011;58:2380-5.

53. Pisters R,Lane DA,Nieuwla at R,de Vos CR Crijns HJ, Lip GY. A novel user-friendly score (HAS BLED) to assess 1-year risk of major bleeding in patients with atrial fibrillation: the Euro Heart Survey.Chest 2010;138:1093-100.

54. Gallego P. Roldan V,Torregrosa JM, et al. Relation ofthe HASBLED bleeding risk score to major bleeding,cardiovascular events, and mortality in anticoagulated patients with atrial fibrillation.Circulation Arrhythmia and electrophysiology 2012;5:312.8.

55. Risk factors for stroke and efficacy of antithrombotic therapy in atrial fibrillation. Analysis of pooled data from five randomized controlled trials. Archives of internal medicine 1994;154:1449-57.

56. De Caterina R, Husted S, Wallentin L, et al. New oral anticoagulants in atrial fibrillation and acute coronary syndromes: ESC Working Group on Thrombosis-Task Force on Anticoagulants in Heart Disease position paper.Journal of the American College of Cardiology 2012;59:1413-2S.

57. Morgan CL, McEwan P,TukiendorfA,Robinson PA, Clemens A,PlumbJM.Warfarin treatment in patients with atrial fibrillation: observing outcomes associated with varying levels of INR control. Thrombosis research 2009; 124:37.41.

58. Suriapranata IM,Tjong WY, Wang T, et al. Genetic factors associated with patient-specific warfarin dose in ethnic Indonesians. BMC medical genetics 2011;12:80.

59. Connolly SJ, Ezekowitz MD, YusufS,et al. Dabigatran versus warfarin in patients with atrial fibrillation. The New England journal of medicine 2009;361:1139-51.

60. Ezekowitz MD, Wallentin L, Connolly SJ, Parekh A, Chernick MR, Pogue J,Aikens TH, Yang S, Reilly PA, Lip GY, Yusuf S. Dabigatran and warfarin in vitamin $\mathrm{K}$ antagonistnaïve and experienced cohorts with atrial fibrillation.Circulation.2010;122(22):2246-2253.

61. Patel MR,Mahaffey KW,Garg J, PanG,Singer DE,Hacke 
W,Breithardt G,Halperin JL, Hankey GJ,Piccini JP, Becker RC, Nessel CC, Paolini JF, Berkowitz SD,Fox KA,Califf RM.Rivaroxaban versus warfarin in nonvalvular atrial fibrillation. N EngIJ Med. 2011;365(10):883-891.

62. Connolly SJ, Eikelboom J, Joyner C, Diener HC, Hart R, Golitsyn S, Flaker G, Avezum A, Hohnloser SH,Diaz R, Talajic M,Zhu J,Pais P, Budaj A,Parkhomenko A,Jansky P,Commerford P, Tan RS, Sim KH, Lewis BS,Van Mieghem W,Lip GY, Kim JH, Lanas.Zanetti F, Gonzalez Hermosillo A,Dans AL, Munawar M, O’Donnell M, Lawrence J, Lewis G, Afzal R,Yusuf S. Apixaban in patients with atrial fibrillation.N EngIJ Me d.2011;364(9):806-817.

63. Granger CB,Aiexander JH,McMurray JJ,Lopes RD,Hylek EM, HannaM,AI-Khalidi HR,Ansell J,Atar D,Avezum A, Bahit MC Diaz R,Easton JD,Ezekowitz JA, Flaker G,Garcia D,Geraldes M, Gersh BJ,Golitsyn S, Goto S,Hermosillo AG,Hohnloser SH,Horowitz J,Mohan P, Jansky P, Lewis BS, Lopez-Sendon JL, Pais P, Parkhomenko A, Verheugt FW, Zhu J,Wallentin L. Apixaban versus warfarin in patients with atrial fibrillation. N EngIJ Med.2011;365(11):981.992.

64. Bayard YL, Omran H, Neuzil P, et al. PLAATO (Percutaneous Left Atrial Appendage Transcatheter Occlusion) for prevention of cardioembolic stroke in non-anticoagulation eligible atrial fibrillation patients: results from the European PLAATO study. Eurolntervention: journal of EuroPCR in collaboration with the Working Group on Interventional Cardiology of the European Society of Cardiology 2010;6:220-6.

65. ParkJW,Bethencourt A, Sievert $\mathrm{H}$,et al. Left atrial appendage closure with Amplatzer cardiac plug in atrial fibrillation: initial European experience. Catheterization and cardiovascular interventions : official journal of the Society for Cardiac Angiography \& Interventions 2011;77:700-6.

66. Holmes DR,ReddyVY,Turi ZG,et al. Percutaneous closure ofthe left atrial appendage versus warfarin therapy for prevention of stroke in patients with atrial fibrillation: a randomised noninferiority trial. Lancet 2009;374:534-42.

67. ReddyVY, Holmes D,Doshi SK, Neuzil P, Kar S.Safety of percutaneous left atrial appendage closure: results from the Watchman Left Atrial Appendage System for Embolic Protection in Patients with AF (PROTECT AF) clinical trial and the Continued Access Registry. Circulation 2011 ;123:417-24.

68. Lip GY,Larsen TB, Skjoth F, Rasmussen LH. Indirect comparisons of new oral anticoagulant drugs for efficacy and safety when used for stroke prevention in atrial fibrillation.Journal of the American College of Cardiology 2012;60:738-46.

69. Freeman JV, Zhu RP, Owens DK, et al. Cost-effectiveness of dabigatran compared with warfarin for stroke prevention in atrial fibrillation.Annals of internal medicine $2011 ; 154: 1-11$.

70. Shah SV,Gage BF. Cost-effectiveness ofdabigatran for stroke prophylaxis in atrial fibrillation.Circulation $2011 ; 123: 2562-70$.
71. Banerjee A Lane DA Torp-Pedersen C. Lip GY. Net clinical benefit of new oral anticoagulants (dabigatran, rivaroxaban, apixaban) versus no treatment in a 'real world' atrial fibrillation population: a modelling analysis based on a nationwide cohort study. Thrombosis and haemostasis 2012;1 07:584-9.

72 Skanes A(.Healey JS,CairnsJA,et al. Focused 2012 update of the Canadian Cardiovascular Society atrial fibrillation guidelines:recommendations for stroke prevention and rate/ rhythm control. The Canadian journal of cardiology. 2012;28(2):125-136.

73. Barrett YC Wang Z, Frost C. Shenker A. Clinical laboratory measurement of direct factor $\mathrm{Xa}$ inhibitors: anti-Xa assay is preferable to prothrombin time assay. Thrombosis and haemostasis $2010 ; 1$ 04:1263-71.

74. Pengo V,Crippa L, Falanga A, et al. Questions and answers on the use of dabigatran and perspectives on the use of other new oral anticoagulants in patients with atrial fibrillation. A consensus document of the Italian Federation of Thrombosis Centers (FCSA).Thrombosis and haemostasis $2011 ; 1$ 06:868-76.

75. Huisman MV, Lip GY,Diener HC Brueckmann M,van Ryn J,Clemens A. Dabigatran etexilate for stroke prevention in patients with atrial fibrillation: resolving uncertainties in routine practice.Thrombosis and haemostasis 2012;1 07:838-47.

76. Sie P, Samama CM, Godier A, et al. Surgery and invasive procedures in patients on long-term treatment with direct oral anticoagulants: thrombin or factor-Xa inhibitors. Recommendations of the Working Group on Perioperative Haemostasis and the French Study Group on Thrombosis and Haemostasis. Archives of cardiovascular diseases $2011 ; 1$ 04:669-76.

77. Omran H, Bauersachs R, Rubenacker S, Goss F, Hammerstingl C. The HAS-BLED score predicts bleedings during bridging of chronic oral anticoagulation. Results from the national multicentre BNKOnline bRiDging REgistRy (BORDER). Thrombosis and haemostasis 2012;1 08:65-73.

78. Nagarakanti R,Ezekowitz MD, Oldgren J,et al. Dabigatran versus warfarin in patients with atrial fibrillation:an analysis of patients undergoing cardioversion.Circulation 2011;123:131-6.

79. Lakkireddy D,ReddyYM,DiBiase L, et al. Feasibility and safety of dabigatran versus warfarin for periprocedural anticoagulation in patients undergoing radiofrequency ablation for atrial fibrillation: results from a multicenter prospective registry.Journal of the American College of Cardiology 2012;59:1 168-74.

80. Carlos Brotons JC Gregory Lip, Kathryn Taubert. Atrial fibrillation in primary care: bringing atrial fibrillation practice closer to guidelines. In: International Atrial Fibrillation Association SAfE, World Heart Federation ed.2012.

81. Pool PE, Herron JM, Rosenblatt S, et al. Sustained release diltiazem: duration of antihypertensive effect.Journal of clinical pharmacology 1989;29:533-7.

82. de Muinck E, Wagner G,vd Ven LL, Lie Kl.Comparison ofthe 


\section{Jurnal Kardiologi Indonesia}

effects oftwo doses ofbisoprolol on exercise tolerance in exercise induced stable angina pectoris. European heart journal 1987;8 Suppl M:315.

83. Stout SM, Nielsen J, Welage LS, et al. Influence of metoprolol dosage release formulation on the pharmacokinetic drug interaction with paroxetine.Journal of clinical pharmacology 2011;51:38996.

84. Gillis AM,Verma A,Talajic M,Nattel S,Dorian P,Committee CCSAFG.Canadian Cardiovascular Society atrial fibrillation guidelines 2010: rate and rhythm management. The Canadian journal of cardiology 2011;27:47-59.

85. Practical Rate and Rhythm Management of Atrial Fibrillation: Heart Rhythm Society;2010.

86. Boos CJ, Carlsson J, More RS.Rate or rhythm control in persistent atrial fibrillation? QJM: monthly journal ofthe Association of Physicians 2003;96:881-92.

87. Van Gelder IC Groenveld HF,Crijns HJ, et al. Lenient versus strict rate control in patients with atrial fibrillation. The New England journal of medicine 2010;362:1363-73.

88. Suttorp MJ,Kingma JH, Jessurun ER,Lie AHL, van Hemel NM,Lie Kl. The value of class IC antiarrhythmic drugs for acute conversion of paroxysmal atrial fibrillation or flutter to sinus rhythm.Journal of the American College of Cardiology 1990;16:17227.

89. Dalzell GW,Anderson J,Adgey AA.Factors determining success and energy requirements for cardioversion of atrial fibrillation. The Quarterly journal of medicine 1990;76:90313.

90. Lundstrom T, Ryden L. Chronic atrial fibrillation. Longterm results of direct current conversion.Acta medica Scandinavica 1988;223:53-9.

91. Roy D, Talajic M, Dorian P, et al. Amiodarone to prevent recurrence of atrial fibrillation. Canadian Trial of Atrial Fibrillation Investigators. The New England journal of medicine 2000;342:91320.

92. Hylek EM, Skates SJ, Sheehan MA, Singer DE.An analysis of the lowest effective intensity of prophylactic anticoagulation for patients with nonrheumatic atrial fibrillation. The New England journal of medicine 1996;335:5406.

93. Frick M,Frykman V,Jensen Urstad M,Ostergren J, Rosenqvist M. Factors predicting success rate and recurrence of atrial fibrillation after first electrical cardioversion in patients with persistent atrial fibrillation.Clinical cardiology 2001;24:23844.

94. Hsu LF, Jais P, Sanders P, et al. Catheter ablation for atrial fibrillation in congestive heart failure.The New England journal of medicine 2004;351:2373-83.

95. Yuniadi Y,Moqaddas H, Hanafy DA,Munawar M. Atrial fibrillation ablation guided with electroanatomical mapping system: A one year follow up.Med J lndones 2010;19:172-8.

96. Haissaguerre M, Jais P, Shah DC, et al. Spontaneous initiation of atrial fibrillation by ectopic beats originating in the pulmonary veins. The New England journal of medicine 1998;339:659.66.

97. Martin DO,Saliba W,McCarthy PM,et al. Approaches to restoring and maintaining normal sinus rhythm.Cleveland Clinic journal of medicine 2003;70 Suppi3:S12.29.

98. Aizer A,Gaziano JM,Cook NR,Manson JE,Buring JE,Albert CM. Relation of vigorous exercise to risk of atrial fibrillation. The American journal of cardiology 2009;103:1572.7.

99. Mozaffarian D,Furberg CD,Psaty BM, Siscovick D. Physical activity and incidence of atrial fibrillation in older adults:the cardiovascular health study. Circulation 2008;118:800-7.

100. HeidbuchelH,Panhuyzen. Goedkoop N,Corrado D,etaI. Recommendations for participation in leisure-time physical activity and competitive sports in patients with arrhythmias and potentially arrhythmogenic conditions Part 1: Supraventricular arrhythmias and pacemakers. European journal of cardiovascular prevention and rehabilitation : official journal of the European Society of Cardiology, Working Groups on Epidemiology\&Prevention and Cardiac Rehabilitation and Exercise Physiology 2006;13:475.84.

101. Vahanian A, Baumgartner H,BaxJ,et al. Guidelines on the management of valvular heart disease: The Task Force on the Management of Valvular Heart Disease of the European Society of Cardiology.European heartjournal2007;28:230.68.

102. Hu CL, Jiang H,Tang QZ, et al. Comparison of rate control and rhythm control in patients with atrial fibrillation after percutaneous mitralballoon valvotomy: a randomised controlled study. Heart 2006;92:1096-101.

103. Schmitt J,Duray G,Gersh BJ,Hohnloser SH. Atrial fibrillation in acute myocardial infarction: a systematic review of the incidence,clinical features and prognostic implications. European heartjournal2009;30:1038-45.

104. Lip GY,Huber K,Andreotti F,et al.Management of antithrombotic therapy in atrial fibrillation patients presenting with acute coronary syndrome and/or undergoing percutaneous coronary intervention/ stenting. Thrombosis and haemostasis 2010;103:13-28.

105. Fitzmaurice DA,Hobbs FD, Jowett $S$, et al. Screening versus routine practice in detection of atrial fibrillation in patients aged 65 or over: cluster randomised controlled trial. Bmj 2007;335:383.

106. Wyse DG. Pharmacotherapy for rhythm management in elderly patients with atrial fibrillation. Journal of interventional cardiac electrophysiology: an international journal of arrhythmias and pacing 2009;25:25.9.

107. Hohnloser SH,Pajitnev D, Pogue J, et al. Incidence of stroke in paroxysmal versus sustained atrial fibrillation in patients taking oral anticoagulation or combined antiplatelettherapy: an ACTIVEW Substudy.Journal of the American College of Cardiology 2007;50:2156-61. 
108. Hart RG, Pearce LA, Rothbart RM, McAnulty JH, Asinger RW, Halperin JL. Stroke with intermittent atrial fibrillation: incidence and predictors during aspirin therapy. Stroke Prevention in Atrial Fibrillation Investigators.Journal ofthe American College of Cardiology 2000;35:183-7.

109. Goette A,Bukowska A,Dobrev D, et al. Acute atrial tachyarrhythmia induces angiotensin II type 1 receptor-mediated oxidative stress and microvascular flow abnormalities in the ventricles. European heart journal 2009;30:1411-20.

110. Pieper PG,Balci A,Van DijkAP.Pregnancy in women with prosthetic heart valves. Netherlands heart journal: monthly journalofthe Netherlands Society of Cardiology and the Netherlands Heart Foundation 2008;16:406-11.

111. Crystal E,Garfinkle MS, Connolly SS, Ginger IT,SleikK, YusufSS. Interventions for preventing post-operative atrial fibrillation in patients undergoing heart surgery. The Cochrane database of systematic reviews 2004:CD003611.

112. Burgess DC Kilborn MJ, Keech AC. Interventions for prevention of post-operative atrial fibrillation and its complications after cardiac surgery: a meta-analysis. European heart journal2006;27:2846-57.

113. Mathew JP, Fontes ML, Tudor IC, et al. A multicenter risk index for atrial fibrillation after cardiac surgery.JAMA:the journal of the American Medical Association 2004;291:1720-9.

114. Sawin CT,Geller A, Wolf PA,et al. Low serum thyrotropin concentrations as a risk factor for atrial fibrillation in older persons.N EngI J Med 1994;331:1249-52.

115. Eldar M,CanettiM,Rotstein Z,et al. Significance of paroxysmalatrial fibrillation complicating acute myocardial infarction in the thrombolytic era. SPRINT and Thrombolytic Survey Groups.Circulation 1998;97:965-70.

116. Le Heuzey JY,De Ferrari GM,Radzik D,SantiniM,Zhu J, Davy JM.A short-term,randomized, double-blind,para !lei-group study to evaluate the efficacy and safety of droneda rone versus amiodarone in patients with persistent atrial fibrillation: the DIONYSOS study. Journal of cardiovascular electrophysiology 2010;21:597-605.

117. Munger TM, Packer DL, Hammill SC, et al. A population study of the natural history of Wolff-Parkinson-White syndrome in Olmsted County, Minnesota, 1953-1989. Circulation 1993;87:866-73.

118. Leitch JW, Klein GJ,Yee R,Murdock C. Prognostic value of electrophysiology testing in asymptomatic patients with WolffParkinson-White pattern.Circulation 1990;82:1718-23.

119. Klein GJ, Bashore TM,Sellers TD, Pritchett EL, Smith WM,Gallagher JJ. Ventricular fibrillation in the Wolff-Parkinson-White syndrome. N EngIJ Med 1979;301:1080-5.

120. ZardiniM,Yee R,Thakur RK. Klein GJ.Risk of sudden arrhythmic death in the Wolff-Parkinson-White syndrome: current perspectives. Pacing Clin Electrophysiol1994;17:966-75.

121. Blomstrom-Lundqvist C. Scheinman MM, Aliot EM, et al. ACC/AHA/ESC guidelines for the management of patients with supraventricular arrhythmias--executive summary: a report of the American College of Cardiology/American Heart Association Task Force on Practice Guidelines and the European Society of Cardiology Committee for Practice Guidelines (Writing Committee to Develop Guidelines for the Management of Patients With Supraventricular Arrhythmai s).Circulation 2003;108:1871-909.

122. Han ZH, Li Y, Jiang TY, Wu XS, Gao YC, Chen F. [The incidence and predictor $s$ of atrial fibrillation in hypertrophic cardiomyopathy]. Zhonghua nei ke za zhi [Chinese journal of internal medicine] 2008;47:475-7.

123. Kappenberger L, Linde(.DaubertC,et al.Pa cing in hypertrophic obstructive cardiomyopathy. A randomized crossover study.PIC Study Group. Eur Heart J 1997;18:1249-56. 